\title{
Revising the U.S. Vertical Merger Guidelines: Policy Issues and an Interim Guide for Practitioners
}

Steven C. Salop

Georgetown University Law Center, salop@law.georgetown.edu

Daniel P. Culley

Cleary Gottlieb Steen \& Hamilton, LLP, dculley@cgsh.com

Published version available at: https://academic.oup.com/antitrust/article/4/1/1/2196285/

Revising-the-US-vertical-merger-guidelines-policy

This paper can be downloaded free of charge from:

https://scholarship.law.georgetown.edu/facpub/1530

http://ssrn.com/abstract=2695043

4(1) J. Antitrust Enforcement 1 (2015)

This open-access article is brought to you by the Georgetown Law Library. Posted with permission of the author. Follow this and additional works at: https://scholarship.law.georgetown.edu/facpub

Part of the Antitrust and Trade Regulation Commons, Business Organizations Law Commons, and the Consumer Protection Law Commons 


\title{
Revising the U.S. Vertical Merger Guidelines: Policy Issues and an Interim Guide for Practitioners
}

\author{
Steven C. Salop and Daniel P Culley ${ }^{1}$
}

\section{$\underline{\text { Table of Contents }}$}

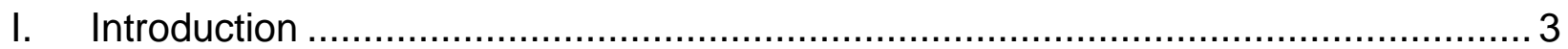

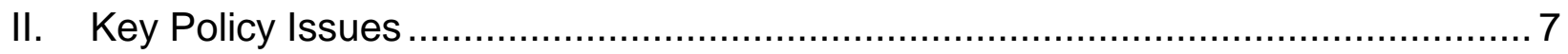

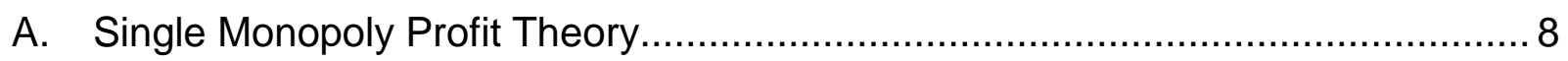

B. Vertical Contracts as a Substitute for Vertical Merger …................................. 9

C. Harm to the Downstream Rivals of Merged Firm .......................................... 10

D. Efficiency Benefits ............................................................................... 11

E. Should Potential Efficiency Benefits Justify Highly Permissive Enforcement

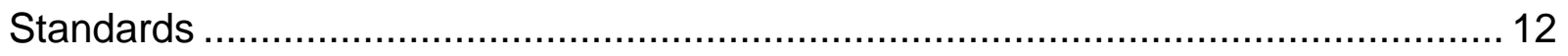

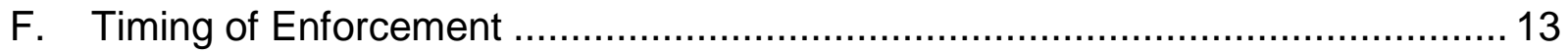

III. Evaluation the Effects of Proposed Vertical Mergers ...................................... 15

A. Market Definition, Market Shares, and Concentration ................................... 18

1 The authors are Professor of Economics and Law, Georgetown University Law Center; Senior Consultant, Charles River Associates (Salop); Associate, Cleary Gottlieb Steen \& Hamilton, LLP (Culley). We would like to thank Joseph Angland, Mark Angland, Jonathan Baker, Matthew Cantor, Dennis Carlton, George Cary, Mark Israel, Francisco-Enrique Gonzalez-Diaz, James Kearl, William Kovacic, James Langenfeld, Mark Levenstein, Doug Melamed, Serge Moresi, Aviv Nevo, Michael Salinger, Carl Shapiro, Joe Sims, Toby Singer, Richard Steuer, and John Woodbury for helpful comments. This article also flows from Professor Salop's ongoing collaboration with Serge Moresi on vertical merger issues. The authors have consulted or represented parties involved in some of the cases used as examples in this article as well as others. All opinions and errors remain our own and do not necessary represent the views of our colleagues or clients. 
B. Elimination or Reduction in Potential Competition ...........................................20

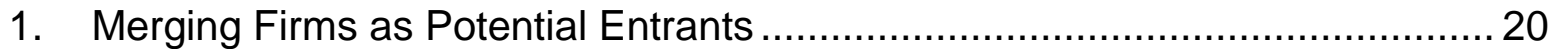

2. Merging Firms as Potential Entry Facilitators.............................................. 21

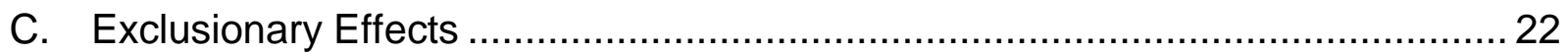

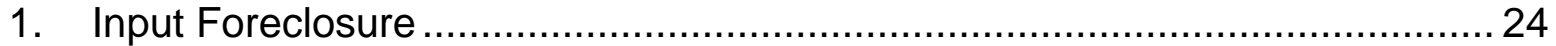

a. Gauging Input Foreclosure Effects ….............................................. 27

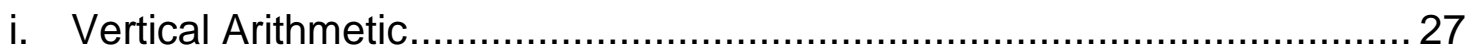

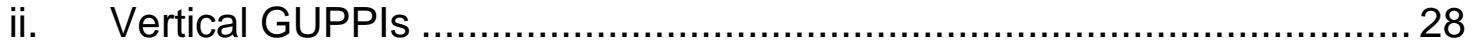

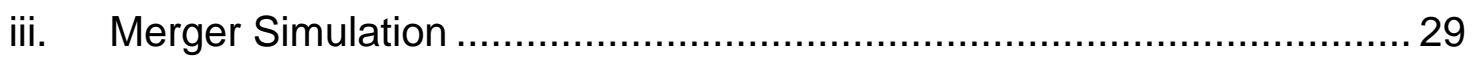

2. Input Foreclosure Threats and Improved Bargaining Position .......................29

3. Customer Foreclosure .......................................................................... 30

4. Misuse of Competitors' Sensitive Information ............................................. 32

D. Unilateral Competitive Incentives to Raise Downstream Prices ........................ 34

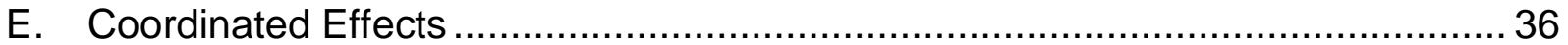

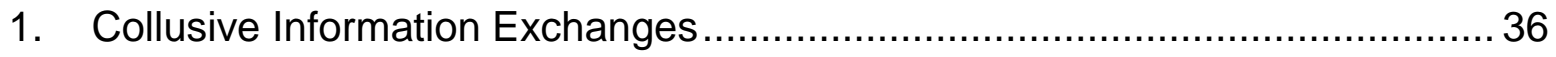

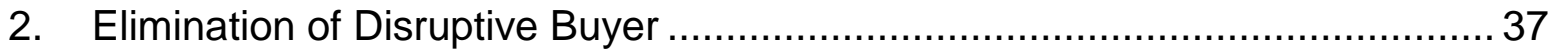

3. Weakening Maverick or Disruptive Competitive Behavior Downstream........... 38

4. Using Lower Costs to Facilitate Consensus or Increase the Ability to Punish

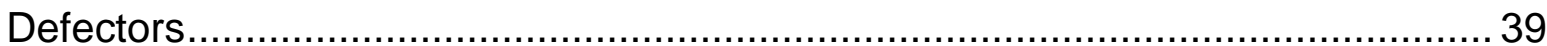

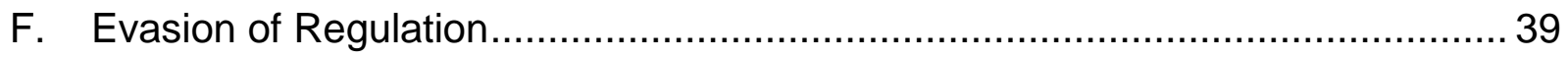

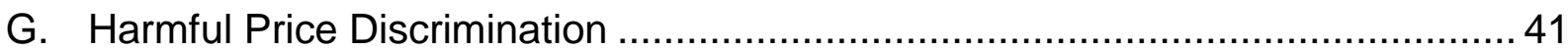

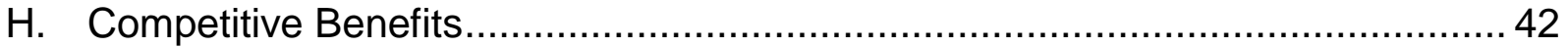

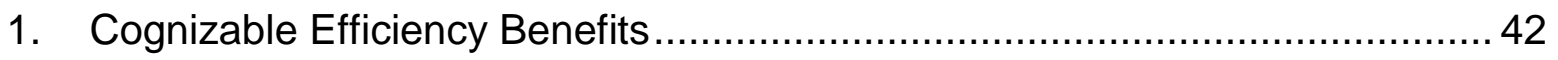

a. Cost and Quality Efficiencies .................................................................. 43

b. Elimination of Double Marginalization.................................................. 44

c. Increased Investment Incentives ............................................................. 46

2. Reduced Likelihood of Coordination .......................................................... 47

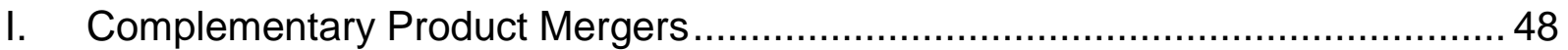

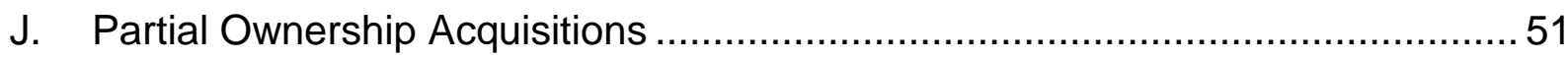

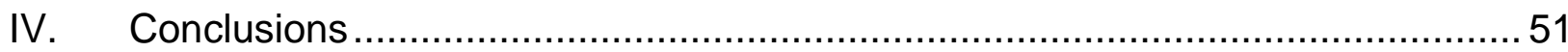




\section{Introduction}

Mergers and acquisitions are a major component of antitrust law and practice. The U.S. antitrust agencies spend a majority of their time on merger enforcement. The focus of most merger review at the agencies involves horizontal mergers, that is, mergers among firms that compete at the same level of production or distribution. Horizontal mergers may involve situations where both merging firms are actual competitors (firms that currently compete in the market). However, mergers can also involve situations where one or both of the firms currently are not actual competitors, but are potential competitors. $^{2}$

Vertical mergers combine firms at different levels of production or distribution. In the simplest case, a vertical merger joins together a firm that produces an input (and competes in an input market) with a firm that uses that input to produce output (and competes in an output market). An acquisition of intellectual property by a company that uses that intellectual property, or who competes with other firms that do, also presents issues vertical merger issues. A merger of firms producing complementary products also is analytically very similar to a vertical merger.

A transaction may involve both horizontal and vertical elements, as when a vertically integrated firm acquires a competitor in one of the markets in which it already competes. In addition, a transaction that is primarily horizontal may involve some vertical elements, if competitors rely to some extent on inputs supplied by one of the merging firms or benefit from product compatibility. For example, interconnection between competitors is a recurring issue in the telecom industry. Similarly, airlines may compete on some routes and act as feeders to one another on other routes.

Over the years, the agencies have issued Merger Guidelines that outline the type of analysis carried out by the agencies and the agencies' enforcement intentions in light of state of the law. These Guidelines are used by agency staff in evaluating mergers, as well as by outside counsel and the courts. Guidelines for horizontal mergers have been issued and revised periodically, in 1968, 1982, 1984, 1992, 1997 and 2010.

Guidelines for vertical mergers were issued in 1968 and revised in 1984 . However, the Vertical Merger Guidelines have not been revised since 1984. ${ }^{3}$ Those Guidelines are

${ }^{2}$ One or both firms can be potential competitors for a product that has not yet been entered the market, for example, new pharmaceuticals that are still undergoing FDA review to evaluate their safety and efficacy for treatment of a particular disease.

${ }^{3}$ U.S. Dep't of Justice, 'Non-Horizontal Merger Guidelines' (1984) [hereinafter, 1984 VMGs], $<w w w$. justice.gov/atr/public/guidelines/2614.pdf>. 
now woefully out of date. ${ }^{4}$ They do not reflect current economic thinking about vertical mergers. ${ }^{5}$ Nor do they reflect current agency practice. ${ }^{6}$ Nor do they reflect the analytic approach taken in the 2010 Horizontal Merger Guidelines. ${ }^{7}$ As a result, practitioners and firms lack the benefits of up-to-date guidance from the U.S. enforcement agencies. ${ }^{8}$ Indeed, the staffs of the FTC and DOJ also lack a coherent, agreed-upon analytic framework or enforcement guidance from their agencies. As a result, there likely is inconsistency between the agencies and perhaps even across staffs within each agency. All in all, there is little transparency in the process. The 2007 Antitrust Modernization Commission and the ABA's 2012 Presidential Transition Report both recommended that the Vertical Merger Guidelines be revised. ${ }^{9}$ However, there have been no efforts in this direction. The current and past directors of the FTC's Bureau of Competition both spoke against the likelihood of revision. ${ }^{10}$

4 Instead, the most modern guidelines are those issued by the European Commission in 2008. European Comm'n, Guidelines on the Assessment of Non-Horizontal Mergers Under the Council Regulation on the Control of Concentrations Between Undertakings, 2008 O.J. C265/6.

${ }^{5}$ For example, see Michael H. Riordan \& Steven C. Salop, Evaluating Vertical Mergers: A Post-Chicago Approach, 63 ANTITRUST L.J. 513 (1995); David Sibley \& Michael J. Doane, Raising the Costs of Unintegrated Rivals: An Analysis of Barnes \& Noble's Proposed Acquisition of Ingram Book Company, in MEASURING MARKET POWER 211 (Daniel J. Slottje ed., 2002); Jeffrey Church, Vertical Mergers, in 2 ABA SECTION OF ANTITRUST LAW, ISSUES IN COMPETITION LAW AND POLICY 1455 (W. Dale Collins ed., 2008); Michael H. Riordan, Competitive Effects of Vertical Integration, in HANDBOOK OF ANTITRUST ECONOMICS 145 (Paolo Buccirossi ed., 2008). See also the sources cited in these articles.

${ }^{6}$ As shown in our review of the cases, the most common allegation involves foreclosure, which is barely mentioned in the 1984 VMGs.

7 United States Department of Justice and Federal Trade Commission, Horizontal Merger Guidelines (August 19, 2010) [hereinafter, 2010 Horizontal Merger Guidelines], $<w w w . f t c . g o v / o s / 2010 / 08 / 100819 \mathrm{hmg} . p d f>$.

8 The same is true for foreign jurisdictions that might look to the U.S. for guidance.

${ }^{9}$ American Bar Association Section of Antitrust Law, 'PRESIDENTIAL TRANSITION REPORT: THE STATE OF ANTITRUST LAW 2012' (February 2013) [hereinafter ABA Report] at 7, $<w w w$.americanbar.org/content/dam/aba/administrative/antitrust_law/at_comments_presidential 201302.authcheckdam.pdf>. Professor Salop was a member of the ABA Taskforce. See also Antitrust Modernization Commission, 'REPORT AND RECOMMENDATIONS 68' (2007) [hereinafter $A M C$ Report]. For a more skeptical view of the need for revising the Guidelines, see Frederick R. Warren-Boulton, The Contribution of the Merger Guidelines to the Analysis of Non-Horizontal Mergers, $20^{\text {th }}$ Anniversary of the 1982 Merger Guidelines: The Contribution of the Merger Guidelines to the Evolution of Antitrust Doctrine, May 21, 2002, <http://www.justice.gov/sites/default/files/atr/legacy/2007/07/11/11709.pdf>.

10 Deborah L. Feinstein, Are the Vertical Merger Guidelines Ripe for Revision, 24 ANTITRUST 5, 6-7 (Summer 2010). Aruna, Viswanatha, New Vertical Merger Guidelines? Not Likely FTC's 
There appear to be several arguments made against revising the Guidelines. One common argument is that the analysis of vertical mergers is well understood, so there is no need for Guidelines. ${ }^{11}$ This argument ignores the fact that vertical merger enforcement involves numerous policy judgments that Guidelines provide. Another argument is that vertical mergers can harm competition in such myriad and complex ways that it would be too difficult to write coherent Guidelines. Aside from the fact that this argument is the opposite of the previous one, it fails to recognize that the complexity is precisely a reason to have Guidelines, to help guide parties and staffs through the complexity to a coherent outcome.

Another argument is that there is so little enforcement that it would not be cost-effective for the agencies to devote all the effort required for revising the Guidelines. This argument ignores the fact that many vertical mergers are cleared without sufficient analysis. It also seems to ignore the benefits of accuracy and optimal deterrence. The current level of enforcement may be too little or too much. A related argument is that revised Guidelines likely would lead to more enforcement. ${ }^{12}$ But that is not necessarily so: a critical reason to promulgate revised Guidelines is to ensure that agency staff make enforcement decisions based on valid, intellectually-supported theories of harm. In any event, it is purely ideological.

Vertical merger enforcement is less common than horizontal enforcement. According to our count, there have been 48 vertical enforcement actions in the 1994-2015 period. Vertical merger challenges also have varied significantly from one administration to another. The DOJ and FTC brought about 31 enforcement challenges during the two Clinton administration terms. During the two G.W. Bush administration terms, the two

Feinstein Says, MainJustice.com (June 11, 2010), <http://www.mainjustice.com/2010/06/11/changes-for-vertical-merger-guidelines/>.

11 Ibid. at 6.

12 See, e.g., AMC Report at 432 (separate statement of Comm'r Kempf). 
agencies brought only 7 enforcement actions. ${ }^{13}$ Through mid-2015, the two agencies in the Obama administration have brought 10 enforcement actions. ${ }^{14}$

\section{Enforcement Actions in Vertical Mergers}

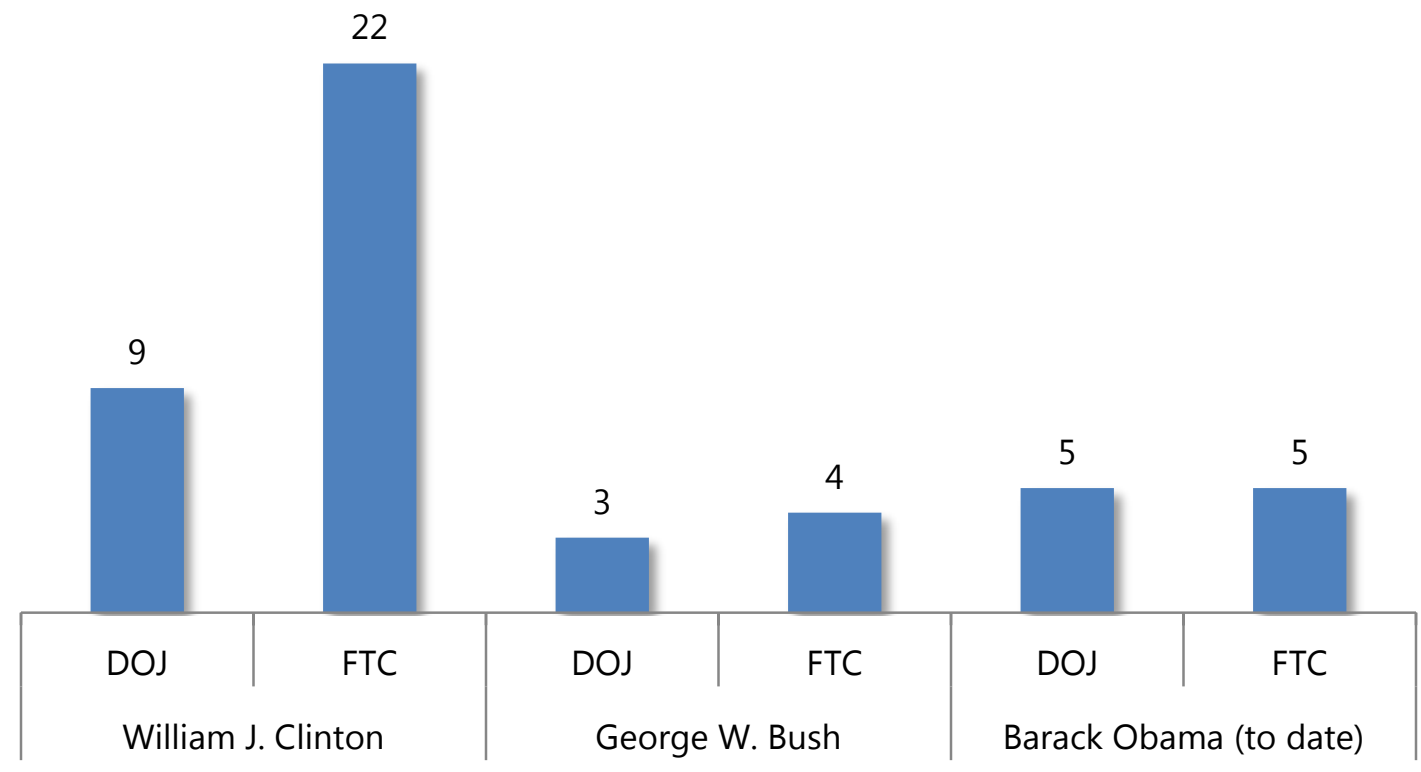

A listing of these cases, the allegations and outcomes are summarized in the online appendix to this article. ${ }^{15}$ Evaluating whether the enforcement has been too intrusive or too permissive is impossible to evaluate without further information. As a result of confidentiality rules and agency tradition, the agencies provide insufficient information about mergers they challenge and almost no information in closing statements for

13 In News Corp.'s acquisition of a stake in the parent company of DirecTV, the DOJ did not take enforcement action in reliance of the FCC's remedy. See (n 73) and accompanying text. We therefore do not include it in our count. We similarly do not include the acquisition of DirecTV by AT\&T in 2015, where the DOJ also did not take enforcement action in reliance of the FCC's remedy. See Press Release, U.S. Dep't of Justice, Justice Department Will Not Challenge AT\&T's Acquisition Of DirecTV (July 21, 2015), http://www.justice.gov/opa/pr/justicedepartment-will-not-challenge-atts-acquisition-directv>.

14 These counts update the earlier enforcement statistics in Steven C. Salop, What Consensus? Why Ideology and Politics Still Matter to Antitrust, 79 ANTITRUST L.J. 601, 624-26 (2014).

15 Steven C. Salop and Daniel P. Culley, Vertical Merger Enforcement Actions: 1994-2015 (프 October 30,2015) < http://papers.ssrn.com/sol3/papers.cfm?abstract_id=2684107>. 
mergers they do not challenge. ${ }^{16}$ Moreover, there is not consensus about the optimal intrusiveness of enforcement, just as there is not for horizontal mergers and other conduct.

In the absence of modern Guidelines, agency staffs and practitioners are forced to muddle through as best they can. They can rely on published economics articles and their economic consultants to provide an analytic framework and possible approaches to proving or disproving harms and benefits. The private bar can parse the very limited explanations provided by the agencies for their enforcement actions. They also can rely on their own experience with vertical transactions and query their partners and friends about current agency practice. This obviously is not ideal, which is why the AMC and ABA Taskforce recommended that the 1984 VMGs be revised.

This article is intended to partially fill the gap in several ways. First, it provides an up-todate analytic framework. It summarizes the various potential harms and benefits from vertical mergers. It also sets out the types of factual and economic issues that practitioners would need to analyze, and questions they would need to ask, in order to predict the likely competitive effects of vertical mergers during the merger review process. However, this article obviously cannot state the current enforcement intentions of the DOJ and the FTC.

Second, the article offers examples from antitrust agency enforcement actions over the past 20 years. These examples (and the online appendix) can provide a database for practitioners and staff that to identify the types of concerns that have been raised. They also can be useful to the agencies in reviewing the confidential analysis they have carried out.

Third, the article identifies a number of key legal and policy issues that are raised by that analysis of vertical mergers. By identifying and analyzing these issues, the policy gap caused by the absence of guidelines can be better understood. The analysis also might point the way to resolution of these policy issues by courts, in the event of adjudication or by the agencies, if and when they carry out the effort to revise the Guidelines.

\section{Key Policy Issues}

Vertical merger enforcement raises a number of policy issues. Some issues touch on all aspects of merger enforcement. We discuss several overarching issues here and

\footnotetext{
${ }^{16}$ The FCC is a welcome exception to this approach. FCC Orders often contain detailed information about agency analysis, though redactions do prevent a full independent evaluation by outsiders.
} 
then discuss the other policy issues as they arise in the context of the specific conduct concerns.

\section{A. Single Monopoly Profit Theory}

It sometimes has been suggested that vertical mergers in unregulated markets are unlikely to raise competitive concerns because there is only a "single monopoly profit" and so monopoly power cannot profitably be extended to other markets. ${ }^{17}$ The validity and applicability of this economic theory to actual vertical mergers has important policy implications. This is because the theory can used to claim that vertical mergers are seldom (if ever) anticompetitive. So, if this theory were found to have wide applicability, it would suggest that vertical merger policy could be very permissive.

However, close analysis of the theory by economists indicates that the conditions for this theory rarely if ever hold. ${ }^{18}$ As a result, the broad claim that there is a single monopoly profit can obscure how a particular merger may raise real competitive concerns. There are several reasons for this conclusion.

First, vertical mergers seldom involve firms that have monopolies protected by prohibitive entry barriers. If there is no monopoly, then there is no single monopoly profit. Instead, as a practical matter, a merger may lead to foreclosure that leads to market or monopoly power in one or both of the markets. ${ }^{19}$ A merger also may permit firms to achieve or enhance express or tacit pricing coordination or parallel accommodating conduct. ${ }^{20}$ Second, even if the upstream firm has a dominant market share, it may face potential competition from downstream firms or other entrants, including its downstream merger partner, and the merger may eliminate the role of the downstream merging partner in facilitating that entry or vice versa. ${ }^{21}$ Third, even where there is dominance and no threat of potential competition, a merger may facilitate

\footnotetext{
17 The classic formulation of the single monopoly profit theory set out in the context of tying is Ward S. Bowman, Tying Arrangements and the Leverage Problem, 67 YALE L.J. 19 (1957).

${ }^{18}$ Since Bowman's article, numerous authors have explained the limitations and general inapplicability to the theory. See Church, (n 5) at 1470; Riordan, (n 5) at 10-12; Riordan \& Salop, (n 5) at 517-518. Einer Elhauge, Tying Bundled Discounts, and the Death of the Single Monopoly Profit Theory, 123 HARV. LAW. REV. 397, 419-421 (2009); See Curtis M. Grimm, Clifford Winston, \& Carol A. Evans, Foreclosure of Railroad Markets: A Test of Chicago Leverage Theory, 35 J.L. \& ECON. 295 (1992).

${ }^{19}$ E.g., Church, (n 5) at 1462-63.

${ }^{20}$ Riordan, (n 5) at 29.

${ }^{21}$ Church, (n 5) at 1487-1488.
} 
harmful price discrimination or evasion of price regulation. ${ }^{22}$ For these reasons, the single monopoly profit theory is not an appropriate rationale for limiting vertical merger enforcement generally.

Even with these limitations, the intuition flowing from the single monopoly profit theory may have other implications for merger policy. The theory sometimes is used to argue that dominant firms may be able to extract profits from other levels of distribution premerger through conduct such as non-linear pricing. This same argument would apply to the firm's pre-merger ability to eliminate double marginalization. Where this pre-merger conduct occurs, these effects should not be double-counted in analyzing the merger. Thus, the theory might suggest that unilateral effects concerns and elimination of double marginalization benefits may be less significant than otherwise thought. But the magnitude of those effects would vary, based on the conditions in an individual market, and so would need to be evaluated on a case-by-case basis.

\section{B. Vertical Contracts as a Substitute for Vertical Merger}

Economics teaches that firms sometimes can use vertical contracts to achieve their goals, as a substitute for vertical integration by merger. ${ }^{23}$ These goals could encompass goals that encompass either competitive harms, particularly from exclusion, or efficiency benefits. This theory could have implications for merger policy. On the benefit side, this theory might be used to argue that certain efficiency claims are not merger-specific. On the harm side, it might be argued that the absence of pre-merger exclusionary contracts implies that the merging firms lack the incentive to engage in conduct that would lead to harmful exclusionary effects. ${ }^{24}$ The existence of harmful exclusionary conduct might suggest that a vertical merger would worsen the situation.

However, there are clear limitations to the applicability of these theories to merger policy. ${ }^{25}$ There often are contractual impediments, such as transaction costs or

\footnotetext{
22 Riordan \& Salop, (n 5) at 562-63.

${ }^{23}$ Joseph T. Mahoney, The Choice of Organizational Form: Vertical Financial Ownership Versus Other Methods of Vertical Integration, 13 STRATEGIC MANAGEMENT JOURNAL 559, 564-66 (1992); Blair, R. D. and D. L. Kasserman, Law and Economics of Vertical Integration and Control, 18-23 (Academic Press, New York, 1983); See Coase, The Nature of the Firm, 4 ECONOMICA 386, 191-92 (1937); Oliver E. Williamson, The Vertical Integration of Production: Market Failure Considerations, 61 AMERICAN ECONOMIC REVIEW 112, 115 (1971).

${ }^{24}$ Dennis Carlton \& Bryan Keating, Rethinking Antitrust in the Presence of Transaction Costs: Coasian Implications, 46 REV. INDUS. ORG. 307, 311-313 (2015).

${ }^{25}$ The FCC recognized the limitations of these arguments in reviewing the News Corp./DTV transaction. See Fed. Commc'ns Comm'n, Memorandum Opinion and Order, In re Applications of General Motors Corporation and Hughes Electronics Corporation, Transferors, and The News
} 
incomplete contracting, to achieving efficiencies through contract. ${ }^{26}$ Anticompetitive vertical contracts may face the same types of impediments as procompetitive ones and a vertical merger can be used to overcome the impediments. On the harm side, anticompetitive vertical contracts also may be deterred by potential Section 1 enforcement. ${ }^{27}$ Thus, while it would be interesting to know whether the firms have attempted exclusionary contracts, neither of these arguments thus can justify a less intrusive vertical merger policy.

\section{Harm to the Downstream Rivals of Merged Firm}

One key policy issue that would need to be resolved in revised Vertical Merger Guidelines is whether (if ever) harm to downstream rivals is sufficient for enforcement, absent evidence of likely or potential harm to consumers who purchase from downstream firms. The policy might not be the same for every type of harm. ${ }^{28}$ For example, harm to the downstream competitors might be viewed by the agencies and courts as sufficient, if the concern is that the merger would create hub-and-spoke collusion in the input market. However, if the concern is that the merger would cause exclusionary effects, then it might be necessary to show harm to consumers who purchase the downstream product. This latter approach would be consistent with the general view that harm to competition must be shown in exclusionary conduct allegations, not simply harm to competitors.

Corporation Ltd., Transferee, MB Dkt. No. 03-134, FCC Rcd. 03-330 (January 14, 2004), $<$ https://apps.fcc.gov/edocs_public/attachmatch/FCC-03-330A1.pdf>.

${ }^{26}$ Coase, (n 23) at 191-92; Williamson, (n 23) at 115-117.

${ }^{27}$ For example, while the merging firms may have had the incentive to achieve exclusionary effects through exclusionary contracts in the pre-merger world, such contracts may have been subject to a variety of impediments, such as bargaining, coordination, informational, and free rider problems. A vertical merger may be a more effective way to avoid these "transaction costs" and achieve anticompetitive profits. Second, Section 1 of the Sherman Act is also a transaction cost that may deter anticompetitive contracts. Thus, the theoretical possibility that the parties or non-merging firms did not implement exclusionary conduct via contract firms does not indicate that the vertical merger enforcement is unnecessary, any more than the theoretical possibility that parties could achieve efficiencies through contract would indicate that analyzing efficiencies is unnecessary.

${ }^{28}$ The 2010 Horizontal Merger Guidelines do not require a showing of harm to consumers in the case of buyer-side horizontal mergers, only harm to the upstream buyers. The Horizontal Merger Guidelines do not explain how to balance these harms against any efficiencies that would reduce the cost of the merging firms and be passed through to consumers. See 2010 Horizontal Merger Guidelines § 12. 


\section{Efficiency Benefits}

Like horizontal mergers, vertical mergers may lead to efficiency benefits that can mitigate or prevent competitive harms. Coordinating the efforts of firms at different levels of production and distribution can lead to reduced costs and improved product quality. We discuss these benefits in detail below.

Some may argue that the potential (or inevitability) of such efficiencies should immunize all vertical mergers from challenge, at least until harms are shown after the merger is consummated. However, there are several flaws in this argument. First, like horizontal mergers, these benefits might be obtained without a merger. ${ }^{29}$ Second, there also may be many situations where vertical integration does not lead to efficiency benefits or where the likely benefits would not outweigh the likely harms. ${ }^{30}$ Some types of efficiencies also may be more difficult to achieve than in a horizontal merger because the acquiring firm may lack expertise about the technology and business of the acquired firm. Firms also may sacrifice potential efficiencies from elimination of double marginalization in order to maintain the incentives of the executives in each division. Thus, it cannot be assumed that significant cognizable efficiencies would occur in every vertical merger. For these same reasons, it also cannot be assumed that efficiencies likely would be sufficient to reverse likely competitive harms. For example, we discuss later on the offsetting incentives that offset elimination of double marginalization. It is our view that, like horizontal mergers, the potential benefits and harms from vertical mergers should be evaluated on a case-by-case basis.

This same type of argument also might suggest that the burden of proof placed on the parties to show efficiencies could be achieved from the vertical merger. Like horizontal mergers, the parties are in a better position to develop such evidence than are the agencies to prove the absence of efficiencies. We do not expect the agencies or the courts to deviate from that view with respect to vertical mergers. ${ }^{31}$ Where particular types of efficiencies have proven more likely to be cognizable and substantial than others, the agencies might adjust their level of initial skepticism, just as they do for horizontal mergers. ${ }^{32}$ Moreover, in light of the ability of the merging parties to develop

\footnotetext{
${ }^{29}$ E.g., Church, (n 5) at 1495.

${ }^{30}$ E.g., Salop \& Riordan, at 524.

31 In evaluating intrabrand price restraints, for example, the Leegin Court opted for the standard rule of reason. It did not place a higher burden of proof on the plaintiff to show competitive harm.

322010 Horizontal Merger Guidelines $\S 10$ (noting, for example, that efficiencies from rebalancing production across formerly separately-owned facilities are particularly likely to be substantial and cognizable).
} 
evidence of likely efficiencies and agencies and courts to evaluate such evidence, there seems to be no reason to assume a larger (and biased) error rate for evaluating vertical mergers.

\section{E. Should Potential Efficiency Benefits Justify Highly Permissive Enforcement Standards}

Discussions of revision of the Vertical Merger Guidelines can be stymied by initial policy disagreements about how permissive or restrictive the Guidelines should be, in light of the potential for efficiency benefits. For example, a presumption of inevitably large efficiency benefits might suggest placing a higher evidentiary burden on the agencies to justify a challenge to a vertical merger. ${ }^{33}$

Disagreement on these same issues with respect to horizontal mergers has not prevented policymakers from formulating useful guidance. As discussed in the previous section, one cannot conclude that vertical mergers invariably lead to large efficiencies. Nor does empirical evidence support the view that vertical mergers never cause competitive harm. ${ }^{34}$ Nor can one equate harm to competition from harm to competitors

33 For a general discussion of the relationship between competitive presumptions and evidentiary burdens, specifically applied to horizontal mergers, see Steven C. Salop, The Evolution and Vitality of Merger Presumptions: A Decision-Theoretic Approach, 80 ANTITRUST L.J. 301 (2015).

${ }^{34}$ While this is not the place to do a complete literature survey, we note it sometimes is suggested that empirical studies demonstrate that vertical mergers inevitably or generally create larger efficiency benefits and are competitively benign. For example, see Dissenting Statement of Commissioner Joshua D. Wright, In the Matter of Par Petroleum Corporation/Koko'oha Investments, Inc. (Mid Pac Petroleum, LLC) FTC File No. 141-0171

(March 18, 2015), citing James C. Cooper, et al., Vertical Antitrust Policy as a Problem of Inference, 23 INT'L J. INDUS. ORG. 639 (2005); Francine Lafontaine \& Margaret Slade, Exclusive Contracts and Vertical Restraints: Empirical Evidence and Public Policy, in HANDBOOK OF ANTITRUST ECONOMICS (Paolo Buccirossi, ed., 2008). The weight of these empirical studies for policymaking is highly limited. Vertical integration is complicated and the impact can differ, depending on the factual circumstances. The particular selection of the studies and methodology in the articles cited by Wright is not random, but is affected by data availability. Several of the studies of vertical integration also were stock market event studies, which are subject to significant criticism. In addition, studies that examine behavior in settings where anticompetitive conduct would have been deterred by the antitrust laws create a sample is biased towards finding no harm. Thus, they cannot provide reliable information about how the likely effects of the practices if the laws were relaxed to permit these practices by firms better situated to cause competitive harm. Jonathan B. Baker, Taking the Error Out of "Error Cost" Analysis: What's Wrong with Antitrust's Right, 80 ANTITRUST L.J. 1 (2015). The surveys also are incomplete. For example, recent rigorous studies of cable TV that have found evidence of competitive harms from vertical mergers. Goolsbee found that vertical integration in cable TV had led to customer foreclosure not motivated by efficiencies. Austan Goolsbee, Vertical 
from exclusionary conduct. Finally, given the tools and resources, agency staff and the parties are well-qualified to evaluate the likely efficiencies and harms. ${ }^{35}$ Therefore, revised Gguidelines could take a compromise approach of setting out the analytics and then refining presumptions on the basis of experience with more rigorous tools.

\section{F. Timing of Enforcement}

Another policy issue involves the timing of remedial action. Like horizontal mergers, vertical mergers are covered by Section 7 of the Clayton Act. They similarly are reportable under the Hart-Scott-Rodino (HSR) Act. It nonetheless has been suggested that enforcement policy towards vertical (or complementary product) mergers should be different, at least with respect to the exclusionary effects concerns, in particular, that the agencies should wait and bring enforcement action against anticompetitive exclusionary conduct under Section 1 or Section 2, only if and when the conduct is actually attempted in the future. ${ }^{36}$

One rationale for this view is that the agency's prediction that the firms will have the incentive for exclusionary conduct may turn out to be incorrect. Another rationale relates to remedy. It is common for agencies to remedy exclusionary concerns with conduct remedies, rather than by enjoining the merger or mandating a divestiture. If the remedy involves requiring the merging firm to agree to deal with unintegrated rivals or restrict price increases, then those remedies might be delayed until if and when actual anticompetitive conduct materializes.

While relying solely on post-merger challenges might appear to have appealing simplicity, several key facts favor immediate enforcement under Section 7 for vertical

Integration and the Market for Broadcast and Cable Television Programming, FCC Media Ownership Study (2007). See also the application of Goolsbee's approach to Comcast and the retrospective determination of the competitive harms caused by the NewsCorporation/DirecTV transaction that was carried out by the FCC staff in its review of the Comcast/NBCU merger. See Fed. Commc'ns Comm'n, 'Technical Appendix' in Memorandum Opinion and Order, In re Applications of Comcast Corp., General Electric Co. and NBC Universal, Inc., MB Dkt. No. 1056, 26 FCC Rcd. 4238 (January 18, 2011) ("2011 FCC Comcast/NBCU Order"), <https://transition.fcc.gov/FCC-11-4.pdf>. For the application to health care markets, see Martin Gaynor, Is Vertical Integration Anticompetitive? Definitely Maybe (But That's Not Final), $25 \mathrm{~J}$. HEALTH ECON 175 (2006).

35 For example, see the detailed analysis of vertical foreclosure concerns evaluated by the FCC in the Comcast/NBCU merger. Ibid. This work is summarized in two articles by Jonathan Baker. Jonathan B. Baker, Comcast/NBCU: The FCC Provides a Roadmap for Vertical Merger Analysis, 25 ANTITRUST 36 (Spring 2011); Jonathan B. Baker et. al., The Year in Economics at the FCC, 2010-11: Protecting Competition Online, 39 REV. IND. ORG 297, 302-304 (2011).

${ }^{36}$ ABA Report at 8-9. 
mergers, just as there is immediate enforcement for horizontal mergers: The fundamental rationale for HSR review is to prevent the delays and limitations inherent in after-the-fact enforcement.

First, consumers would suffer harms during the interim until liability has been established and a remedy put into place. The ability of the merged firm to delay resolution of the matter could entail a long lag before the harm is remedied.

Second, immediate enforcement prevents potentially severe problems in remedying the concern. It may be too late to unwind the merger after the fact. By the time the case reaches the remedy stage, the market structure may have irreversibly changed. For example, the exclusion may already have driven the excluded rivals irreversibly to exit from the market. Therefore, the only possible remedy might be for the antitrust agencies and the courts to engage in long term direct regulation of the prices, quality, and product designs of the merged firm, a task that they are not well-suited to undertake.

Third, the anticompetitive conduct may not even be detected after-the-fact. Vertical mergers can create coordinated effects that suffer from the same type of detection issues as horizontal mergers. Exclusionary conduct may be hard to distinguish from "normal" changes in prices and quality.

Fourth, Section 1 and Section 2 legal standards are more permissive than Section 7 standards. Those statutes do not reflect the incipiency and detection concerns that drove the adoption and implementation of Section 7.37 Those standards also may reflect greater concerns about deterring procompetitive unilateral conduct for a single entity, as well as concerns about the workability of remedies that are not present in the context of analyzing a merger. For example, administrative and other concerns have led to more permissive Section 2 standards with respect to enforcing rules against anticompetitive refusals to deal. ${ }^{38}$ Some courts similarly have adopted standards for bundle pricing with above-cost safe harbors that are similar to predatory pricing standards and that would permit unbundled component price increases (i.e., bundle discounts) without fear of liability in markets with significant margins. ${ }^{39}$ Product

\footnotetext{
${ }^{37}$ For example, in the horizontal merger context, after-the-fact cases attacking post-merger collusion suffer from detection problems and the fact that conscious parallelism does not violate Section 1.
}

38 Verizon Communications v. Law Offices of Curtis V. Trinko, LLP, 540 U.S. 398, 414-15 (2004).

${ }^{39}$ E.g., Cascade Health Solutions v. PeaceHealth, 515 F.3d 883 (9th Cir. 2008). 
incompatibility also might be subject to a very permissive standard unless it can be shown that the incompatibility lacks any efficiency benefits. ${ }^{40}$

All in all, failure to address these kinds of issues in the context of pre-merger review through the HSR process could lead to significant consumer harm and underdeterrence. Thus, while post-merger reviews can occur, just as they do for consummated horizontal mergers, there are strong policy reasons not to rely solely on post-merger enforcement. At the same time, pre-merger enforcement decisions ought to be based on inferences from reliable evidence, not speculation.

\section{Evaluation the Effects of Proposed Vertical Mergers}

We turn next to the analytics of evaluating competitive harms and competitive benefits for specific, proposed vertical mergers. Like horizontal mergers, most vertical mergers do not raise competitive concerns and likely are procompetitive. Firms at different levels of production may need to cooperate in order to design, produce and distribute their goods and services. Vertical mergers may increase the efficiency of this process by eliminating the need for inter-firm contracting, improving communication, and harmonizing the incentives of the merging firms. ${ }^{41}$ These benefits may include cost reduction and improved product design that can lead to lower prices, higher-quality products, and increased investment and innovation. ${ }^{42}$ By reducing the cost of inputs used by the downstream division of the merged firm, a vertical merger also can create an incentive for price reductions. In markets vulnerable to coordination, a vertical merger might lead to creation or enhancement of a maverick or disruptive firm, or it might disrupt oligopoly coordination in other ways. ${ }^{43}$

Vertical mergers also can raise various competitive concerns. As noted in the DOJ's Policy Guide to Merger Remedies, "vertical mergers can create changed incentives and enhance the ability of the merged firm to impair the competitive process." 44 As a result, vertical mergers can lead to the achievement, enhancement, or maintenance of market power that harms consumers and competition. Vertical mergers also can facilitate the harmful exercise of pre-existing market power. All of these effects can lead to higher

40 E.g., Berkey Photo v. Eastman Kodak Co., 603 F.2d 263, 287 (2d Cir. 1979).

${ }^{41}$ Church, (n 5) at 1493-95.

${ }^{42}$ See Riordan \& Salop, (n 5) at 523-24.

${ }^{43}$ See Jonathan B. Baker, Mavericks, Mergers, and Exclusion: Proving Coordinated Competitive Effects under the Antitrust Laws, 77 N.Y.U. L. REV. 135, 179, 182-85 (2002).

44 U.S. Dep't of Justice, Antitrust Division Policy Guide to Merger Remedies 5 (2011), $<w w w . j u s t i c e . g o v / a t r / p u b l i c / g u i d e l i n e s / 272350$.pdf $>$. We do not discuss remedies in this article. 
prices, reduced product quality, reduced variety and lessened investment and innovation. The goal of vertical merger law and policy is to deter, block, or remedy mergers that likely may lead to these harmful effects. These competitive benefits and harms similarly can occur from mergers of firms producing complementary products.

This article classifies these potential harms into several general categories: potential competition effects; exclusionary effects; unilateral effects; coordinated effects; regulatory evasion; and facilitation of harmful price discrimination. The latter two categories involve the impact of the merger on the exercise of pre-existing market power, whereas the others involve achieving, enhancing or maintaining market power.

Because these effects can be overlapping and mutually reinforcing, the organizational structure of this article is not the only possible approach. Some of the specific effects classified under a particular category could have been classified instead under another category. For example, an exclusionary effect may facilitate coordination or may be enhanced by the existence of coordination. Information exchanges can have both coordinated and exclusionary effects.

A vertical merger also may raise multiple concerns that involve effects in more than a single category. When the Vertical Merger Guidelines are revised, the agencies might choose to organize the categories differently or prioritize some of competitive concerns over others. ${ }^{45}$

The 48 mergers challenged in the 1994-2015 period involved a variety of allegations of potential harm and some matters involved multiple categories of allegations. Elimination of potential competition was alleged in 8 matters, foreclosure in 36 matters, misuse of competitors' sensitive information to exclude in 23 matters, collusive information exchange in 11 matters, elimination of a disruptive buyer or other facilitating effects in 3 matters, and evasion of regulation in 2 matters. Unilateral effects and price discrimination were discussed but were not specifically alleged as harms in any of the matters.

45 We follow the Horizontal Merger Guidelines in discussing the harms before the benefits. This organization is not intended to reflect a presumption that the typical vertical merger likely is harmful. 


\section{Enforcement Actions by Theory}

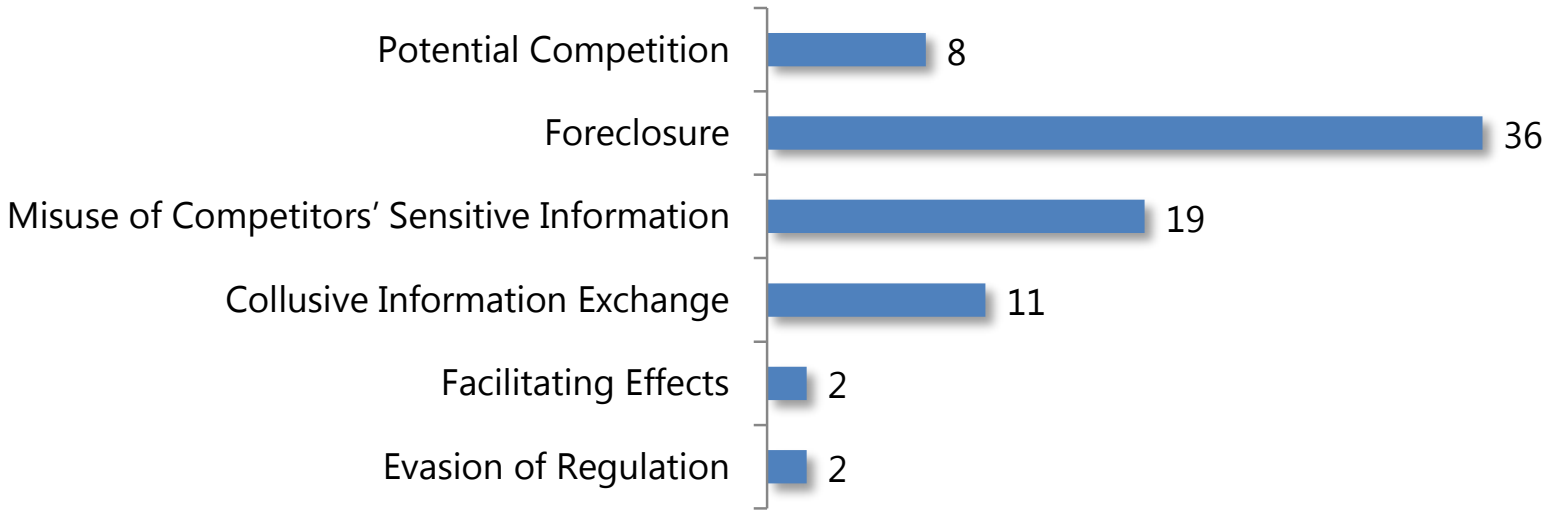

While the details of the analysis vary for different categories of concerns, the focus of the competitive effects analysis is the same - to predict whether or not the merger may lead to higher prices or other harmful effects in the markets affected by the merger. A vertical merger can affect competition in either of or both the upstream (input) market and the downstream (output) market. It is also possible that additional markets will be adversely affected by the merger. ${ }^{46}$ In analyzing these markets, the identification of which is the upstream market and which is the downstream markets may vary. For example, distributors often are literally the customers of manufacturers, but distribution services also are a critical input required by manufacturers. Thus, it is at times useful to treat distributors as input providers rather than as customers.

As with horizontal mergers, a full analysis of the competitive effects of a vertical merger would examine the potential competitive benefits and harms in order to predict the likely net competitive effect on consumers and competition. The fact that multiple markets normally are affected makes the analysis more complex. It also raises a legal and policy issue when competition is harmed in one market but benefited in another market. This is policy issue that will need to be resolved in revised Guidelines.

46 Exclusionary or coordinated effects could lead to effects in output markets in which the
downstream firms compete but do not use the input. For example, if there are strong
economies of scope, then input foreclosure in the downstream market could lead to higher
prices in the related market. Similarly, there could be effects in input markets in which the
upstream firms compete but the downstream division of the merged firm does not compete. 


\section{A. Market Definition, Market Shares, and Concentration}

Section 7 of the Clayton Act prohibits mergers whose effect "may be substantially to lessen competition, or to tend to create a monopoly," where those harms may occur "in any line of commerce or in any activity affecting commerce in any section of the country." In current practice, a "line of commerce" generally is interpreted as a relevant product market while a "section of the country" is interpreted as a relevant geographic market. There is a large literature on relevant market definition and this topic is treated in detail in the 2010 Horizontal Merger Guidelines. The same basic principles of market definition apply to vertical mergers as they do for horizontal mergers.

Market shares and concentration have traditionally played a large role in merger analysis, but that role has evolved over time. The Horizontal Merger Guidelines have safe harbors and anticompetitive presumptions based on the $\mathrm{HHI}$ measure of market concentration.

In a vertical merger, there are two separate markets to analyze, the upstream input market and the downstream output market. In the case of a vertical merger involving a manufacturers, the distribution market might be viewed an input into the sale of the manufactured product, or the distributors might be considered the customers of the manufacturers. Which approach is more useful to evaluating competitive effects will depend on the mechanism of competitive harm. In the case of complementary product mergers, there are the products for the two complementary products and there also may be a third related market for the "system" that is created by the complementary components. There similarly may be third markets that are affected by vertical mergers.

Unlike horizontal mergers, there is no change in the HHls for purely vertical mergers. However, the market shares of the merging firms and the HHls at the upstream and downstream levels can be relevant to evaluating a vertical merger. They also in principle might be used to create safe harbors or anticompetitive presumptions. ${ }^{47}$ For example, the 1984 Vertical Merger Guidelines suggested a quasi-safe harbor for markets that were not highly concentrated. Whether to include safe harbors and anticompetitive presumptions, and what form they should take, is another policy issue that would be considered when the Guidelines are revised.

In our view, the agencies should be cautious about using market share and $\mathrm{HHI}$ measures as summary measures of competitive concerns in vertical mergers. For

\footnotetext{
47 Several modified "vertical HHI" measures have been proposed in the economic literature, based on different economic models of the upstream market. See Joshua S. Gans, Concentration-Based Merger Tests and Vertical Market Structure, 50 J.L. \& EcoN. 661 (2007). If the Vertical Merger Guidelines are revised, some might support including those "vertical HHIs" for reference in the Guidelines.
} 
example, the upstream merging firm may currently have a large market share, but that share may not be reflective of market power if other competitors have the ability and incentive to rapidly expand and do not have capacity constraints. If that is the case, attempting input foreclosure of the downstream firm's rivals may be unprofitable. Similarly, the upstream merging firm may currently have a small market share, but its ability and incentive to rapidly expand may be disciplining the pricing of other upstream firms. If that is the case, the merger might lead to profitable input foreclosure by permitting the other upstream firms to raise their prices, disadvantaging the downstream firm's rivals.

Vertical mergers may also raise unilateral effects concerns, both directly and through foreclosure strategies, as discussed below. The $\mathrm{HHI}$ and market shares may not be the best proxies for evaluating these concerns. As noted in the 2010 Horizontal Merger Guidelines, the agencies "rely much more on the value of diverted sales than on the level of the $\mathrm{HHI}$ for diagnosing unilateral price effects in markets with differentiated products." 48 Similarly targeted metrics such as vertical GUPPIs can be used for analyzing certain concerns in vertical mergers.

Market shares also may provide poor proxies for certain types of concerns about coordination. For example, a low market share is not inconsistent with the upstream merging firm being a maverick or disruptive firm, or with the downstream merging firm being a disruptive buyer. Similarly, market shares are not generally relevant to the ability and incentive to use one of the divisions to exchange competitively sensitive information with rivals in the other market, although the HHIs and market shares may provide some indication about the likely gains and harmful effects from doing so.

If the agencies were to create safe harbors or presumptions for vertical mergers based on HHIs, the standard HHIs clearly provide only a partial picture. In addition to the usual market HHIs for the two markets, the agencies also should calculate supplementary HHIs for hypothetical markets that do not include the merging firms. ${ }^{49}$ Removing the impact of each of the merging firms would be more relevant to the vulnerability of the market to coordination adverse to the non-merging firms, if either the upstream firm withdrew its inputs from the downstream firm's rivals, or if the downstream firm removed its demand from the upstream firm's rivals when there are no

\footnotetext{
482010 Horizontal Merger Guidelines § 6.1.

49 For example, if the pre-merger market has 5 firms, each with a share of $20 \%$, then the market $\mathrm{HHI}$ is 2000 . The market absent the merging firm would have 4 firms, each with a share of $25 \%$. This modified $\mathrm{HHI}$ level would be 2500 . These measures also are correlated in that relatively low standard $\mathrm{HHI}$ plus low market shares of the merging parties would lead to a relatively low modified $\mathrm{HHI}$.
} 
other buyers. These measures might then be relevant when evaluating input and customer foreclosure.

If the agencies are committed to formulating safe harbors based on these statistics, a combination of measures might be used. In particular, if both merging firms have low shares and the standard and these modified HHIs in both markets also are below a certain level (e.g., the threshold for an unconcentrated market in the Horizontal Merger Guidelines), the agencies might conclude without further analysis that a vertical merger is unlikely to raise competitive concerns. Whether to adopt concentration-based safe harbors or anticompetitive presumptions, and the appropriate concentration levels to use, would be an important issue for revised VMGs.

\section{B. Elimination or Reduction in Potential Competition}

A vertical merger can eliminate one of the merging firms as a potential entrant or facilitator (or sponsor) of entry into the other firm's market. While these issues arise in a vertical merger, they can be construed as a type of unilateral horizontal concern, and so the agencies may have paid closer attention to this category of harm in the past.

\section{Merging Firms as Potential Entrants}

Pre-merger, either or both of the merging firms could be potential entrants into the other firm's market. Established firms competing in adjacent markets may be well-situated to enter because they may have expertise relevant to that market or easier access. The fear of entry by a customer or supplier may serve as a constraint on the pre-merger prices of a firm. The merger would reduce or eliminate this constraint. If either of the merging firms is the most likely perceived or actual potential entrant (or among a few most likely potential entrants) into the other's market, then the merged firm may be able to raise (or maintain supracompetitive) prices in the affected market.

Example: The DOJ's analysis of the Live Nation/Ticketmaster merger in 2010 raised potential competition concerns in that Live Nation was a potential entrant into ticketing. Ticketmaster also may have been a potential entrant into promotion and venues. ${ }^{50}$

50 Competitive Impact Statement, United States v. Ticketmaster Entertainment, Inc., No. 1:10cv-00139 (D.D.C. Jan. 25, 2010), <www.justice.gov/atr/cases/f254500/254544.pdf>. See also John E. Kwoka, Jr, Rockonomics: The Ticketmaster-Live Nation Merger and the Rock Concert Business, in John E. Kwoka, Jr. \& Lawrence J. White, THE ANTITRUST REVOLUTION (6th Ed.) 62 (2014) 
Example: The FTC's enforcement action in 2013 against the Nielsen/Arbitron merger raised a somewhat different type of "future market" potential competition issue. While Nielsen sold TV audience data and Arbitron sold radio audience data, both firms apparently were both potential entrants into the sale of "hybrid" (multimedia) audience data, an anticipated future market. ${ }^{51}$

The following information would be particularly relevant to evaluating these potential competition concerns:

- Analysis of the pre-merger market structure in the upstream and downstream markets, with a focus on whether either of the merging firms currently has significant market power and whether entry would make a material difference to competition.

- Evaluation of whether or not one or both of the merging firms are potential competitors (either actual or perceived potential entrants) into the market of the other, including any concrete plans for entry.

- Evaluation of whether or not there are sufficient other potential entrants equally well-positioned to replace the loss of any potential competition provided by the merging firms.

\section{Merging Firms as Potential Entry Facilitators}

Rather than enter itself, each of the merging firms could facilitate entry by cooperating with or becoming a sponsor of potential entrants into the other firm's market. After the merger, the incentive to facilitate that entry might be eliminated. In fact, the firm might go further by refusing to deal with the new entrant or by creating incompatible products that would be unusable by an unintegrated entrant. ${ }^{52}$ Either way, potential entrants might then be forced to enter both markets simultaneously. ${ }^{53}$ The need for two-level entry could reduce the likelihood of entry for several reasons, including potentially greater risk, higher sunk costs,

\footnotetext{
51 Analysis Of Agreement Containing Consent Order To Aid Public Comment, In re Nielsen Holdings, N.V. and Arbitron, Inc., No. 131-0058 (F.T.C. Sept. 20, 2013), <www.ftc.gov/sites/default/files/documents/cases/2013/09/130920nielsenarbitronanalysis.pdf>.

52 For this reason, this category of conduct could be classified as an exclusionary effect, as discussed See Section III.C.

53 The 1984 VMGs discuss the potential harms from requiring two-level entry. The focus of that analysis is placed on differences in required scale for entry; in particular, the potential need for greater capital, acquisition of skill sets in both markets, or to either achieve minimum efficient scale by producing at a greater than optimal scale in the primary market or operate inefficiently in the secondary market. 1984 VMGs, (n 3) at §§ 4.211-4.212.
} 
higher minimum viable scale, or lack of expertise or other resources needed to successfully enter the additional market. By raising the cost, or reducing or eliminating the likelihood of entry, the merged firm may be able to raise or maintain supracompetitive prices in the affected market.

Example: The goal of the DOJ's original divestiture remedy proposal in the Microsoft case in 2000 was to create potential competition for a standalone Windows Operating System company from a divested Office Applications company. ${ }^{54}$

In addition to the information listed in Section III.B.1 above, the following information would be relevant to evaluating these potential competition concerns:

- Information relevant to evaluating ease of entry and the degree to which potential entry is a significant constraint on pricing.

- Evaluation of whether and by how much simultaneously entry into both markets would create greater impediments to entry.

- Evaluation of whether either of the merging firms has plans or has made moves to facilitate or sponsor entry into the other firm's market.

\section{Exclusionary Effects}

Exclusionary effects have been one of the primary potential concerns arising in vertical mergers. ${ }^{55}$ Foreclosure concerns were raised in 36 of the 48 vertical merger challenges. Exclusionary effects can lead to harm not only to the downstream competitors, but also to the customers of the downstream firms.

Exclusionary effects can, under some circumstances, lead to harm to competitors in the form of higher input costs, but not higher downstream prices. A focus on consumer welfare would suggest that adverse downstream effects would be necessary for enforcement from these exclusionary concerns, not merely harm to downstream competitors. As noted earlier, this policy issue would need to be resolved in the Vertical Merger Guidelines.

${ }^{54}$ Plaintiffs' Memorandum in Support of the Final Judgment, IV.A.2, United States v. Microsoft Corporation, 97 F. Supp. 2d (D.D.C. Apr. 28, 2000) (No. 98-1232), $<w w w . j u s t i c e . g o v / a t r / c a s e s / f 219100 / 219107 . p d f>$.

55 Exclusionary concerns also can arise in horizontal mergers. See 2010 Horizontal Merger Guidelines at $\S 6$. 
There are several mechanisms by which these exclusionary effects can occur. ${ }^{56}$ First, the merger could lead to input foreclosure, by which the upstream division of the merged firm restrict supply, degrades quality, or raises the input prices charged to targeted (or all) rivals of the downstream division of the merged firm, and thereby gives the downstream division the power to raise its price. The upstream division alternatively might threaten to deny access or degrade quality in order to increase its bargaining power to negotiate a higher input price.

Second, a merger could lead to customer foreclosure, by which the downstream division of the merged firm reduces or stops purchasing inputs from the other upstream firms, which then can disadvantage those firms and provide the upstream division of the merged firm with the power to raise its price to downstream firms. Alternatively, the downstream division of the merged firm might threaten to refuse to purchase in order to induce the independent input suppliers to raise prices to or withhold inputs from the merged firm's downstream rivals.

These two types of foreclosure can function independently or can reinforce one another in combination. For example, if customer foreclosure leads to downstream rivals paying higher input prices, that effect can cause input foreclosure. Other markets also might be affected. For example, if downstream rivals are disadvantaged by input foreclosure and there are economies of scope with another product, the downstream division of the merged firm may gain the power to raise prices in that other product market, even though the input sold by the upstream division is not used to produce that other product. This concern may be particularly relevant for high-technology markets.

Third, the merger could provide the downstream division of the merged firm with access to sensitive competitive information of its competitors from the upstream division of the merged firm, which the downstream firm can use to more rapidly respond to or even preempt competitive moves by these competitors, and deter such competitive moves as result. ${ }^{57}$

It is important to emphasize that the economic concept of foreclosure is not well gauged by simple "foreclosure rate" discussed in some antitrust cases. Foreclosure is substantial if it significantly increases the costs, restricts the output of the targeted victim, restricts its ability to expand in a cost-efficient way, or causes it to exit or significantly reduce its investment. Foreclosure thus can be substantial even if the rivals remain viable and even

\footnotetext{
56 The 1984 VMGs do not focus on foreclosure aside from the two-level entry problem. Foreclosure is mentioned but not analyzed in detail. See 1984 VMGs, (n 3) at § 4.212 \& n. 31.

57 Access to competitively sensitive information can also facilitate coordination, as discussed in more detail, Section III.E.1.
} 
if they can achieve minimum efficient scale of production. Even if the simple foreclosure rate is low, the targeted firm may significantly lose competitiveness, for example, if the unrestrained substitutes are less efficient or if their producers lack sufficient capacity or if they have incentives and ability to coordinate. Foreclosure also can lead to increased barriers to entry or expansion by fringe firms. By contrast, even if the simple foreclosure rate is high, rivals may not be significantly disadvantaged in the market if they have sufficient cost-effective alternatives. Consumers also may have cost-effective alternatives even if foreclosed rivals are disadvantaged.

\section{Input Foreclosure}

A vertical merger can lead to the upstream division of the merged firm denying (i.e., restricting supply) its input, degrading the quality of the input sold, or discriminating by raising the input price to one or more targeted non-merging firms. If the targeted rivals cannot substitute to other equally cost-effective inputs, their costs will be raised. This may occur if substitutes are inferior or more costly, or if the foreclosure conduct by the upstream firm gives the non-merging input producers unilateral or coordinated incentives to raise their prices. In addition, input foreclosure also might be used to disadvantage a maverick or disruptive downstream competitor and thereby facilitate coordination. ${ }^{58}$ If this foreclosure conduct materially raises the costs or reduces the quality of the targeted rivals, or their output or their ability to expand in a cost-effective way, the result may be higher quality-adjusted prices and reduced output or expansion by these targeted rivals. It also may cause the rival to reduce its investment. If there are insufficient non-targeted competitors or other products that provide consumers with close substitutes, then the merging downstream firm will gain the ability to raise its price profitability. Fear of being targeted for input foreclosure also might deter entry. As a result, consumers and competition may be harmed. ${ }^{59}$

The harmful effects in the downstream market may involve a unilateral price increase by the downstream division of the merged firm. In response, the targeted and other nonforeclosed downstream rivals also typically would further raise their prices, which could cause further price increases by the downstream division. However, these harmful effects in the downstream market are not inevitable. Continued competition, expansion, and repositioning by non-targeted rivals, vertically-integrated competitors, and competing products that use other inputs may deter post-merger price effects.

58 This issue is discussed in more detail in Section III.E.3.

59 For detailed analysis of input foreclosure, see Riordan and Salop, (n 5) at 528-551; see also 1984 VMGs, (n 3) at § 4.212. 
Raising the price of the input generally would be more profitable than totally withholding access to the input or degrading its quality. ${ }^{60}$ Restricting supply may be a second-best strategy when prices are regulated or price increases are constrained by most-favored nation provisions. Degrading quality also may be less detectable than price increases.

Example: In the AT\&T/McCaw merger in 1994, the DOJ's concerns amounted to a fear that AT\&T would engage in input foreclosure against McCaw's wireless competitors. ${ }^{61}$

Example: In the Google/ITA merger in 2011, the DOJ's input foreclosure concerns were that Google might withhold, degrade, or raise the price of ITA's travel data to Google's competitors in a comparative flight search market. ${ }^{62}$

Example: In the Comcast/NBCU merger in 2011, the DOJ's and FCC's input foreclosure concerns were that the merged firm might withhold or raise the price of NBCU content to Comcast's MVPD competitors. ${ }^{63}$

The value of sales diverted to the downstream division of the merged firm leads to an incentive to raise the price of the upstream division of the merged firm. Raising the costs of targeted rivals will also cause upward pressure on their prices, holding other prices constant. The value of diverted sales and the upward pricing pressure generally will be higher when the diversion from targeted rivals to the downstream division of the merged firm is higher, and when the profit margin earned by the downstream division of the merged firm on incremental sales is higher. ${ }^{64}$

60 Threatening non-price foreclosure may be used to increase bargaining power, but may never need to be implemented, or may be implemented only temporarily when the bargaining process breaks down.

61 Competitive Impact Statement, United States v. AT\&T Corp., No. 1:94-cv-01555 (D.D.C. July 15, 1994), 59 Fed. Reg. 44,158, <www.gpo.gov/fdsys/pkg/FR-1994-08-26/html/94-20948.htm>.

62 Competitive Impact Statement, United States v. Google, Inc., No. 1:11-cv-00688 (D.D.C. Apr. 8, 2011), <www.justice.gov/atr/cases/f269600/269620.pdf>. See also Michael D. Topper, Stanley Watt, and Jingming "Marshall" Yan, Google-ITA: Creating a New Flight Search Competitor, in Kwoka and White, (n 51) at 385.

63 Competitive Impact Statement, United States v. Comcast Corp., No. 1:11-cv-00106 (D.D.C. Jan. 18, 2011), <www.justice.gov/atr/cases/f266100/266158.pdf>. See also FCC Comcast/NBCU Order, (n 34); Baker, (n 35).

64 It should be noted that any efficiencies from the merger that increase gross margins, including elimination of double marginalization, will also increase the merged firm's incentive to foreclose rivals. This effect must be taken into account when assessing the net impact of the transaction. The FCC recognized this issue in analyzing the News Corp./DTV acquisition, though it lacked adequate evidence to analyze its impact. See Fed. Commc'ns Comm'n, Memorandum Opinion 
In analyzing both input and customer foreclosure concerns, the following general market information would be relevant:

- Pre-merger market structure and competition in input and output markets.

- Impact of the merger on market structure and incentives in the input and output markets.

- Ability and incentive of non-merging input suppliers and downstream competitors to continue to compete, if foreclosed by merging firm.

- Behavior and market impact of other integrated firms.

- Existence, structure (including any exclusionary provisions), and competitive effects of other vertical contracts by the parties or other firms in the markets.

Beyond the general analysis of the markets, the following information also could aid in the evaluation of the potential upstream and downstream effects of input foreclosure:

- Identification of downstream rivals likely targeted for a foreclosure strategy of either raising price, restricting supply, or degrading quality.

- Ability of the targeted downstream rivals to substitute to other equally cost-effective input suppliers and the capacity and incentives of those input suppliers, including any impact of any reduced input purchases by the downstream division of the merged firm.

- Determination of whether the other input suppliers would have the unilateral incentives to raise their prices, or the incentive and ability to raise prices in coordination with one another, if the upstream division of the merged firm were to engage in an input foreclosure strategy.

- The resulting extent to which downstream rivals' costs would be raised (or quality decreased) if the upstream division of the merged firm refuses to sell or degrades the quality of its input or raises its input price to the targeted downstream rivals, or restricts their cost-effective ability to expand.

- Evaluation of whether there are downstream firms (including vertically integrated competitors) that have alternative access to inputs from other upstream firms or upstream entry so that they will not be disadvantaged by (or targeted for) any foreclosure that occurs.

and Order, In re Applications of General Motors Corporation and Hughes Electronics Corporation, Transferors, and The News Corporation Ltd., Transferee, MB Dkt. No. 03-134, FCC Rcd. 03-330 (January 14, 2004) , <https://apps.fcc.gov/edocs_public/attachmatch/FCC-03330A1.pdf>. 
- Evaluation of the residual competitive constraints provided by these non-targeted downstream competitors.

- Evaluation of competitive constraints provided by other products that do not use the inputs supplied by the upstream division of the merged firm and its competitors.

- Information relevant to estimating the rate at which variable cost increases of the upstream and downstream are passed through as higher prices.

- Information from natural experiments relevant to estimating diversion ratios resulting from foreclosure.

- Input pricing and sales conduct of other integrated firms in the market and evaluation of any impact on downstream prices.

- Evaluation of the market impacts, if any, of other vertical contracts that involve exclusivity or favoritism.

\section{a. Gauging Input Foreclosure Effects}

When there is sufficient data available, input foreclosure incentives might be further scored with several quantitative methodologies.

\section{i. Vertical Arithmetic}

The vertical arithmetic methodology is a critical loss analysis that evaluates the profitability of a non-price foreclosure tactic such as restricting supply to targeted rivals of the downstream division of the merged firm. ${ }^{65}$ The methodology compares the reduction in incremental profits borne by the upstream division from reducing its input sales to targeted

65 This methodology flows directly from the analytic framework in Riordan \& Salop, (n 5). See also Steven C. Salop, Stanley M. Besen, John R. Woodbury \& E. Jane Murdoch, An Economic Analysis of Primestar's Competitive Behavior and Incentives (FCC Submission Jan. 7, 1998) (on file with authors); Sibley, (n 5) ; Daniel Rubinfeld, The Primestar Acquisition of the News Corp./MCI Direct Broadcast Satellite Assets, 16 REV. INDUS. ORG. 193 (2000); Steven C. Salop, Carl Shapiro, David Majerus, Serge Moresi \& E. Jane Murdoch, Charles River Assocs., News Corporation's Partial Acquisition of DIRECTV: Economic Analysis of Vertical Foreclosures Claims (FCC Submission July 1, 2003), <http://apps.fcc.gov/ecfs/document/view.action?id=6514283359>; For the recent application in Comcast/NBCU, see Baker, (n 35). Baker also reviews the empirical evidence that profitable input foreclosure of programming occurred from the News Corporation/DirecTV transaction. Other articles have applied the framework to as diverse situations as local-exchange carrier regulation and book distribution. See David S. Sibley \& Michael J. Doane, Raising the Costs of Unintegrated Rivals: An Analysis of Barnes \& Noble's Proposed Acquisition of Ingram Book Group in MEASURING MARKET POWER (2002) at 211; David S. Sibley \& Dennis L. Weisman, The Competitive Incentives of Vertically Integrated Local Exchange Carriers: An Economic and Policy Analysis, 17 J. Pol. Anal. \& Mgmt. 74 (1998). 
firms versus the gains in incremental profits achieved by the downstream division when some of the sales of the targeted rivals are diverted to the downstream division. That foreclosure may be permanent; or it might be carried out only for a limited period of time to cause customer diversion this is slow to reverse. The data used for this methodology includes the incremental profit margins for the upstream and downstream divisions of the merged firm and the likely diversion from targeted downstream rivals to the downstream division in the event that the upstream division forecloses access of its input to those targeted rivals.

The vertical arithmetic methodology is most relevant where the concern is restricting supply. A limitation of the methodology is that it evaluates only whether sales restrictions at current prices are profitable, not whether they are profit-maximizing. When the foreclosure concern is an increase in price, rather than restricting supply, the vertical arithmetic methodology is a less precise and more permissive test. The vertical arithmetic methodology cannot determine the profit-maximizing price increase. It also does not use the information about demand elasticities that is inherent in the pre-merger profit margins. The methodology also does not take efficiency benefits into account, nor does it permit balancing of harms against benefits. However, it retains some usefulness.

\section{ii. Vertical GUPPIs}

The vertical GUPPI methodology is designed to remedy the limitations of the vertical arithmetic. The vertical GUPPI methodology is based on the value of diverted sales and scores the direct impact of the vertical merger on the unilateral pricing incentives entailed by input foreclosure. ${ }^{66}$ The vGUPPI scores are analytically similar to the GUPPI scores defined implicitly in the 2010 Horizontal Merger Guidelines and are proportional to the profit-maximizing "first round" incentive to raise the prices. Two vGUPPI's are used to score the upward pricing pressure from the input foreclosure. The vGUPPlu gauges the incentive to raise the input prices of the upstream division of the merged firm to targeted downstream rivals. The vGUPPIr gauges the incentive of the targeted rivals to raise their downstream prices in response to the higher input price. ${ }^{67}$ When there are cognizable efficiency benefits or unilateral incentives to raise the price of the downstream division, the vGUPPIr also can be combined with the upward or downward pricing pressure from those effects, as scored by the vGUPPId. ${ }^{68}$

66 Serge Moresi \& Steven C. Salop, vGUPPI: Scoring Unilateral Pricing Incentives in Vertical Mergers, 79 ANTITRUST L.J. 185 (2013).

67 Ibid. Moresi and Salop suggest that the vGUPPIr is the more relevant measure because it relates more closely to the degree of potential consumer harm, as opposed to competitor harm.

68 The vGUPPId is discussed in Sections III.C.1.a.ii and III.H.1. 


\section{iii. Merger Simulation}

As with horizontal mergers, where there is sufficient data, merger simulation models can be used to go beyond vertical arithmetic and vGUPPIs to quantify the equilibrium price effects of vertical mergers. Simulation models in principle can combine the analysis of both harms and benefits into a single structure to predict net effects in the upstream and downstream markets. For example, simulation models were submitted by the parties and extended and evaluated by the FCC in the AT\&T/DirecTV merger. ${ }^{69}$ For horizontal mergers, the 2010 Horizontal Merger Guidelines state that the agencies "do not treat merger simulation evidence as conclusive in itself, and they place more weight on whether their merger simulations consistently predict substantial price increases than on the precise prediction of any single simulation." 70 For this purpose, the agencies typically will examine the assumed demand and econometric structure, the data, and the robustness of the estimates.

\section{Input Foreclosure Threats and Improved Bargaining Position}

In situations where the upstream division of the merged firm negotiates prices with the downstream firms, the upstream firm might use the threat of foreclosure to negotiate higher prices from the rivals of the downstream firm. The bargaining power of the upstream division of the merged firm may be increased by the merger because a failure to reach agreement with a downstream firm would harm the upstream firm less than it did absent the merger. This is because the profits of the downstream merging partner would increase if the agreement were not reached and the downstream rival cannot substitute another upstream provider of the necessary input. This improved alternative for the merged firm generally allows the upstream firm to obtain a higher negotiated payment. ${ }^{71}$

Example: Input foreclosure, and threats of input foreclosure threats to improve bargaining position, were analyzed by the DOJ and FCC in 2011 in the Comcast/NBCU merger, where the issue was the potential that Comcast might have the incentive to withhold or raise the price of NBCU programming to Comcast's MVPD rivals. ${ }^{72}$

\footnotetext{
69 See 'Technical Appendix' in FCC Comcast/NBCU Order, (n 34).

702010 Horizontal Merger Guidelines § 6.1.

71 The underlying economic analysis involves the Nash Bargaining equilibrium. See generally, John Nash, The Bargaining Problem, 18 ECONOMETRICA 155 (1950); Ken Binmore, Ariel Rubinstein and Asher Wolinsky, The Nash Bargaining Solution in Economic Modeling, 17 RAND J.ECON 176 (1986).

72 Competitive Impact Statement, United States v. Comcast Corp., No. 1:11-cv-00106 (D.D.C. Jan. 18, 2011), <www.justice.gov/atr/cases/f266100/266158.pdf>. See also FCC
} 
Example: Foreclosure threats to achieve improved bargaining position also were analyzed by the DOJ and FCC in 2004 in the News Corporation/DirecTV partial ownership acquisition, where the issue was the potential that News Corporation might have the incentive to withhold or raise the price of programming to DirecTV's MVPD rivals. ${ }^{73}$

This incentive to use input foreclosure threats to increase negotiated prices can be scored with an equilibrium bargaining analysis methodology that evaluates the impact of reduction of supply on the profits of the upstream division of the merging firm and a targeted downstream firm. The methodology assumes that a larger relative impact on the profits of the downstream firm will lead to an increase in the negotiated (fixed or variable) payment, relative to the pre-merger price. ${ }^{74}$

\section{Customer Foreclosure}

A vertical merger can lead to the merging downstream firm refusing to buy inputs from non-merging input suppliers. The strategy can disadvantage those upstream rivals and provide the upstream division of the merged firm with the power to raise its input price. Alternatively, the downstream division could use threats not to purchase to induce those input suppliers to raise the prices they charge its downstream rivals. Customer foreclosure can lead to foreclosed rivals reducing investment or even exiting the market in more extreme cases. This actual or threatened customer foreclosure also can create or reinforce input foreclosure by raising the costs of the downstream rival firms. ${ }^{75}$ As a result, downstream rivals and consumers may be harmed by the conduct. ${ }^{76}$

Comcast/NBCU Order, (n 34 ; Baker, (n 35); William P. Rogerson, A Vertical Merger in the Video Programming and Distribution Industry: Comcast/NBCU, in Kwoka and White, (n 50) at 534.

73 The DOJ did not have a consent decree but relied on the FCC Order. Press Release, U.S. Dep't of Justice, Justice Department Will Not Challenge News Corp.'s Acquisition Of Hughes Electronics Corp. (Dec. 19, 2003), $<$ www.justice.gov/archive/opa/pr/2003/December/03_at_714.htm>. In its Comcast/NBCU Order, the Commission reports on an empirical study that indicated that NewsCorporation was able to negotiate higher affiliate fees after the DirecTV transaction. See also FCC Comcast/NBCU Order, (n 34) ; Baker, (n 35) .

74 For several analyses, see the sources (n 72-73) .

75 Threats of foreclosure are discussed in the 2010 Horizontal Merger Guidelines $\S 8$.

76 For detailed analysis of customer foreclosure, see Riordan and Salop, (n 5) at 528-51; see also 1984 VMGs, (n 3) at §4.212. 
Example: Although the FTC focused only the horizontal aspects of the case in 2014, the private litigation raised customer foreclosure as an issue in the St. Luke's/Saltzer merger. ${ }^{77}$

Example: Customer foreclosure concerns were raised by the FTC in 1997 in the Time Warner/Turner merger, regarding the possibility that Time Warner Cable would refuse to carry Fox News or MSNBC, which were competitors' to Turner's CNN network. ${ }^{78}$

Example: Customer foreclosure concerns were analyzed in the Comcast/NBCU merger by the FCC in 2011. The customer foreclosure issue was whether Comcast would deny carriage to competitors of NBCU or provide inferior channel placement. ${ }^{79}$

The analysis of customer foreclosure would include an evaluation of the effects on upstream rivals if they are denied access to significant sales to the downstream division of the merged firm. The conduct can reduce their sales, which can lead them to have higher costs, reduce their incentive to invest, or exit the market. Either way, the upstream division of the merging firm may gain market power in the input market. In addition, because customer foreclosure can cause or reinforce input foreclosure, the information regarding input foreclosure also would remain relevant for the customer foreclosure concern as well. The analysis of bargaining threats and their impact on negotiated prices also can be applied here.

The following specific information also could aid in the evaluation of the potential upstream and downstream effects of customer foreclosure concerns:

77 Findings of Fact and Conclusions of Law, Fed. Trad. Comm'n v. St. Luke's Health System, Ltd., No. 1:13-CV-00116 (Jan. 24, 2014), $<$ www.ftc.gov/system/files/documents/cases/140124stlukesfindings.pdf $>$. For the private case, see Saint Alphonsus Medical Center - Nampa, Inc. et al. v. St. Luke's Health System, Ltd., 2012 WL 6651167, *4 (D. Idaho Dec. 20, 2012). This concern might be classified instead as input foreclosure in that the payers tend to be third-party insurance companies or managed care operators, and that the patients are inputs who are steered to one or another hospital by the doctors. Where the merging firms produce complementary products, it is often possible to categorize the foreclosure either as input or customer foreclosure.

78 Time Warner Inc,123 F.T.C. 171 (1997), $<$ www.ftc.gov/system/files/documents/commission_decision_volumes/volume123/volume123a.pdf\#page=179>.

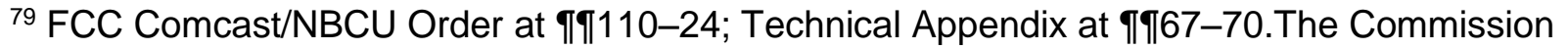
relied on a previous empirical study by Goolsbee that found evidence that cable TV distributors favored their own programming for anticompetitive reasons, not efficiencies. Goolsbee, (n 34) above. The Commission also extended the Goolsbee analysis to Comcast's behavior and found similar results. 
- Evaluation of whether the downstream division of the merged firm would have the ability to shift significant input purchases to the upstream division of the merged firm, and if so, determination of the resulting loss of sales to other upstream firms.

- Evaluation of the impact of those lost sales on the ability of one or more upstream firms to compete, and whether it might lead to the exit of any upstream firms, or higher costs, or reduction in investment incentives.

- Evaluation of whether the downstream division of the merged firm would have the power as a buyer to induce upstream firms to raise the input prices they charge to its downstream rivals (e.g., by threatening not to purchase).

- Whether non-merging upstream firms would have increased opportunities to sell additional inputs to non-merging downstream firms that might no longer wish to deal with the upstream division of the merged firm or would have very elastic demand for their inputs.

- Whether the upstream division of the merging firm or other upstream firms would gain the power to bargain for higher prices with the non-merging downstream firms.

- The resulting impact, if any, on the costs of non-merging downstream firms and downstream competition, as analyzed for input foreclosure.

- Purchase behavior of other integrated firms in the market and evaluation of any market impact.

- Evaluation of the market impacts, if any, of other vertical contracts that involve exclusivity or favoritism.

- Whether the upstream division of the merging firm could fulfill all of the input needs of its downstream division and, if not, the incremental profit margin on sales the downstream division would lose from contracting its output.

\section{Misuse of Competitors' Sensitive Information}

A vertical merger can lead to information transfers from rivals to one division of the merging firm that might be misused strategically by the other division of the merged firm to preempt and thereby deter procompetitive actions by non-merging firms. ${ }^{80}$ If the merging firm obtains a rival's sensitive competitive information and uses it to respond more rapidly to the rival's moves with its own price decreases or product improvements, that might seem to benefit competition. However, this quick response may reduce the incentives of the rivals even to attempt the procompetitive moves, in that their first-

${ }^{80}$ Coordinated effects from information exchanges are analyzed in Section III.E.1HI.E.1. 
mover advantages would be reduced. Thus, consumers may be harmed by the exclusionary effects of such misuse of rivals' information.

Anticipating such misuse of its sensitive information, rivals might choose not to deal with the upstream division of the merged firm after the merger and instead purchase from more expensive or lower quality alternatives. In that case, the competitive harms in the downstream market from the misuse of competitors' sensitive would be replaced by the adverse competitive effects of the rivals essentially being forced by the merger to engage in what could be characterized as "involuntary self-foreclosure."

Example: The FTC's remedies in 2010 of the Coca-Cola/CCE bottler merger and the parallel Pepsi bottler acquisitions focused on potential misuse of information about Dr. Pepper in a way that appeared to raise exclusion concerns. ${ }^{81}$

Beyond the general analysis of the market structure of the downstream and upstream markets, the following information would be relevant to the evaluation of potential misuse of competitors' sensitive information:

- Determination of whether the upstream division of the merged firm has premerger access to sensitive competitive information about downstream firms, such as advance notice of new products or new product specifications.

- Determination of whether the downstream division of the merged firm has premerger access to sensitive competitive information about upstream firms, such as prices, product specifications, or new products or technologies.

- Evaluation of whether the merged firm would be able to use this information to quickly respond to or preempt competitive moves by its competitors.

- Determination of whether fear of competitive preemption likely would lead nonmerging firms to avoid dealing with the merged firm or change the terms of dealing to limit access to the competitive information, even if alternatives were more expensive or lower quality.

81 Analysis of Agreement Containing Consent Order to Aid Public Comment, In re The CocaCola Company, No. 101-0107 (F.T.C. Sept. 27, 2010), <www.ftc.gov/sites/default/files/documents/cases/2010/09/100927cocacolaanal.pdf>; Analysis of Agreement Containing Consent Order to Aid Public Comment, In re PepsiCo, Inc., No. 091-0133 (F.T.C. Feb. 26, 2010), <www.ftc.gov/sites/default/files/documents/cases/2010/02/100226pepsicoanal.pdf>. 


\section{Unilateral Competitive Incentives to Raise Downstream Prices}

A vertical merger may lead to a unilateral incentive for the downstream division to raise its price in order to increase the input sales and incremental profits of the upstream division. ${ }^{82}$ This incentive would occur in situations where the downstream division's rivals purchase inputs from the upstream division of the merged firm. This means that an increase in the price of the downstream division may lead in turn to those downstream firms purchasing additional inputs from the upstream division of the merged firm. The upstream division would then capture incremental profits on those sales that offset the loss of marginal downstream sales. This incentive creates unilateral upward pricing pressure analogous to the unilateral effects of horizontal mergers, as discussed in the 2010 Horizontal Merger Guidelines. ${ }^{83}$

The unilateral incentives of the downstream division to raise price can be gauged in terms of the value of sales diverted to the upstream division of the merged firm in the event that the downstream division of the merged firm were to raise its price by a small, but significant, amount or to reduce its output. ${ }^{84}$ The unilateral incentive to raise the price of the downstream division of the merged firm generally will be higher if the market share of the upstream division of the merged firm is higher, if the profit margin earned by the upstream division of the merged firm on incremental sales is higher, and if the price of its input is a substantial fraction of the downstream firms' total cost of production. The upward pricing pressure from this unilateral incentive alternatively might be small or nonexistent.

This unilateral incentive of the downstream division to raise its price may be mitigated or even reversed by a corresponding unilateral incentive to reduce its price as a result of taking into account in its pricing a lower real resource cost for the inputs purchased from the upstream division of the merging firm, what has been called "elimination of doublemarginalization." 85 The downward pricing pressure from elimination of doublemarginalization might be small or even non-existent. ${ }^{86}$ Thus, while they are distinct, these

82 See Moresi and Salop, (n 66) .

832010 Horizontal Merger Guidelines § 6.1.

${ }^{84}$ After the merger, the unintegrated rivals may not wish to purchase inputs from the upstream division of the merged firm. Substituting to other input suppliers may increase their costs and thereby create competitive concerns, as discussed in Section III.C.1HI.C.1.

85 This "elimination of double marginalization" efficiency claim is discussed in Section III.H.1.bH.H.1.b.

86 There are several reasons why the effect might be small. First, the downstream division of the merging firm may not have the ability to use the inputs produced by the upstream division.

Second, the upstream division may be selling its inputs to the downstream division at a price equal 
two unilateral effects often are evaluated in tandem. ${ }^{87}$ Which incentive likely dominates depends on the facts of the merger. A profit-maximizing downstream division would view the overall company's "opportunity cost" of the input as reflecting the net effect of these two factors.

As in horizontal mergers, the upward pricing pressure may be offset by entry or repositioning by other competitors. Unlike horizontal mergers, however, the exclusionary effects of foreclosure may reduce the likelihood of repositioning and entry.

When there is sufficient data available, the unilateral incentive to raise the downstream price can be gauged by analysis of diverted sales from the downstream division to the upstream division, if the downstream division were to raise its price and lose sales to other firms that purchase inputs from the upstream division. The vGUPPId scores the resulting upward pricing pressure of the price of the downstream division. ${ }^{88}$ This vGUPPId scores the value of diverted sales and depends on the upstream firm's incremental profit margin, the share of the sales lost by the downstream firm that are diverted to other firms that purchase inputs from the upstream division of the merged firm, the magnitude of those likely incremental input purchases by the downstream rivals, along with input and output prices. The vGUPPId also can be extended to take into account the potential effects from elimination of double marginalization. ${ }^{89}$

Beyond the general analysis of the market structure of the downstream and upstream markets, certain information relevant to evaluating these unilateral pricing concerns would include the following:

- If the downstream firm raised price and lost a certain percentage of its sales, the fraction of those sales that would be diverted to other downstream firms which would purchase inputs from the upstream division of the merged firm in order to satisfy their incremental demand.

to marginal cost in the pre-merger market. Third, the merged company may have a policy of each division treating other divisions at arms-length. Fourth, the elimination of double marginalization may not be found to be merger-specific. Elimination of double marginalization is analyzed in more detail along with analysis of other efficiency benefits in Section III.H.

87 This combined analysis was implemented by the FCC for the Comcast/NBCU merger. See FCC Comcast/NBCU Order, Technical Appendix at 9ף56-64. For example, if paid lower affiliate fees than its rivals, then the diversion of subscribers to Comcast would sacrifice those higher affiliate fees.

88 See Moresi and Salop, (n 66) .

89 Ibid. 
- The likely increased input sales by the upstream division as a result of the diverted sales.

- The incremental profit margin of the upstream division of the merged firm and the resulting incremental profits earned by the upstream division of the merged firm on those increased input purchases from the resulting diverted sales.

- The incremental profit margin of the downstream division of the merged firm.

- The potential for repositioning by other downstream firms.

- The potential for rapid entry and longer term entry into the downstream market.

- Evaluation of the pricing behavior of other integrated firms.

\section{E. Coordinated Effects}

A vertical merger might raise several potential coordinated effects concerns in either the upstream market or the downstream market. ${ }^{90}$ First, a vertical merger may facilitate collusive interfirm information exchanges. Second, a vertical merger may facilitate coordination in the upstream market by eliminating the incentives of the downstream division of the merged firm to act as a disruptive buyer that deters coordination by upstream firms. Third, a vertical merger may facilitate coordination in the downstream market by weakening the disruptive behavior of a non-merging downstream firm. This weakening of the maverick or disruptive firm can be implemented with targeted input foreclosure or threats of foreclosure. ${ }^{91}$ Fourth, a vertical merger could facilitate coordination by creating more symmetry in costs or placing the merged firm in a stronger position to punish defectors.

\section{Collusive Information Exchanges}

A vertical merger can lead to coordinated effects concerns by facilitating information exchanges between firms at the same level of production. The downstream division of the merged firm might share information about the prices of the upstream firms with the upstream division of the merged firm, and vice versa. In this way, consensus can be reached or detection lags can be reduced, both of which can facilitate coordinated effects or parallel accommodating conduct.

\footnotetext{
90 Vertical mergers potentially also could reduce the likelihood of coordination, as discussed in Section III.H.2H.H.2.

91 As discussed in the exclusionary effects foreclosure, a vertical merger can facilitate coordination by non-merging firms in the upstream market in response to price increases by the upstream merging firm as part of an input foreclosure strategy.
} 
Example: The DOJ's analysis of the GrafTech/Seadrift merger in 2010 focused on collusive information exchanges, as possibly exacerbated by MFN provisions. ${ }^{92}$

Example: the FTC's analysis in 1998 of the Merck/Medco merger raised concerns about collusive information exchanges facilitated by the merger, as well as input foreclosure. ${ }^{93}$

Relevant information for analyzing this concern includes the following:

- The vulnerability of each market to coordination. ${ }^{94}$

- Whether the downstream division's post-merger incentives will be to continue dealing with upstream firms other than its own upstream division.

- The pre-merger access by the downstream firms to sensitive competitive information about upstream firms, such as price information.

- The pre-merger access by the upstream firms to sensitive competitive information about downstream firms, such as price information.

- An examination of how the merged firm would or would not be able to use this information to facilitate coordination after the merger.

- Evaluation of behavior of other integrated firms in the same markets and their impact on the market.

\section{Elimination of Disruptive Buyer}

A vertical merger can facilitate coordination in the upstream market by eliminating the incentives of the downstream division of the merged firm to act as a disruptive buyer that deters coordination by upstream firms. ${ }^{95}$ After the merger, the merged firm might gain more net profits from that upstream coordination than it loses downstream by possibly having higher input costs. Where the downstream firm is a critical disruptive buyer in the pre-merger market and the upstream market is vulnerable to coordination, this concern

92 Competitive Impact Statement, United States v. GrafTech Int'l Ltd., No. 1:10-cv-02039

(D.D.C. Nov. 29, 2010), <www.justice.gov/atr/cases/f264600/264608.pdf>.

93 Analysis of Proposed Consent Order to Aid Public Comment, In re Merck \& Co., Inc. and Merck-Medco Managed Care, L.L.C., No. C-3853 (F.T.C. Aug. 27, 1998), <www.ftc.gov/sites/default/files/documents/cases/1998/08/9510097ana.htm>.

94 See 2010 Horizontal Merger Guidelines $§ 7.2$.

95 These effects are similar to the analysis of the downstream division coercing non-merging upstream firms to raise prices to its downstream rivals, as discussed in Section III.C.3. 
could lead to higher input prices that would harm non-merging downstream firms and would be passed on to consumers as higher downstream prices.

The following information is relevant to the analysis of this concern:

- The vulnerability of the upstream market to coordination.

- Information regarding whether the downstream division of the merged firm is acting like a disruptive buyer regarding input purchases in the pre-merger market.

- Information regarding whether the downstream division of the merged firm is the unique disruptive buyer or whether other buyers also act in this way.

\section{Weakening Maverick or Disruptive Competitive Behavior Downstream}

A vertical merger can facilitate coordination in the downstream market by weakening maverick or other disruptive competitive behavior of a non-merging downstream firm. ${ }^{96}$ If a non-merging firm is a maverick or otherwise disruptive competitive influence in the premerger market, the upstream division of the merged firm might weaken the incentives for that behavior by raising the price it charges to the disruptive firm or by reducing its access to inputs. Alternatively, the downstream division might use customer foreclosure threats to induce upstream firms to raise their input prices charged to that disruptive firm.

The mechanism for this concern can involve targeted input foreclosure or threats of foreclosure. ${ }^{97}$ As such, the analysis of this concern follows the analysis of input foreclosure set out above. In addition to the information generally relevant to evaluating foreclosure, the following information would be relevant to the analysis of this concern:

- The vulnerability of the downstream market to coordination.

- Information regarding whether one of the non-merging firms has been a maverick in the output market.

- Information regarding whether the merger would permit the upstream division of the merged firm to orchestrate higher input prices or other threats to deter this nonmerging firm's maverick behavior.

\footnotetext{
96 There is not a similar concern about eliminating the downstream division of the merged firm acting as a maverick, unless its maverick behavior involves a willingness to support new entry into the upstream market. If the downstream division of the merged firm were a maverick, there would be no incentive to use the merger to eliminate its maverick behavior, since the downstream division would be made worse off and the upstream division of the merging firm would not gain from downstream coordination.

97 Because this mechanism involves input foreclosure, it also could be classified as an exclusionary effect.
} 


\section{Using Lower Costs to Facilitate Consensus or Increase the Ability to Punish Defectors}

A vertical merger might facilitate coordination by reducing the costs of the merged firm. First, if those lower costs could create more symmetry in costs and structure, it may lead to the firms' having similar desired prices. Second, obtaining lower costs also may place the merged firm in a stronger position to punish defectors, which can deter defection.

A significant policy issue involves the fact that challenging a merger based solely on this effect involves the agency attacking a merger because it reduces the costs of the merged firm. While the lower costs could facilitate coordination, this anticompetitive theory skates close to an "efficiency offense." As a result, the agencies might be reluctant to include it in a revision to the Vertical Merger Guidelines, except perhaps as a rarely applicable issue.

Example: This effect was alleged in 2001 in the Premdor/Masonite merger case. The DOJ's Competitive Impact Statement made the point that the merger would reduce the costs of the merged firm and lead to greater cost symmetry between the merged firm and the other vertically integrated firm. ${ }^{98}$

The following information would be relevant to evaluation of this cost-symmetry concern:

- Evidence regarding whether the downstream market is vulnerable to coordination.

- $\quad$ Determining whether the merger increases cost symmetry by reducing costs.

- Determining if lower costs would significantly increase the ability and incentive to punish defectors from a coordinated agreement or informal understanding.

- Evaluating whether the downward pricing pressure from unilateral effects is more or less significant than the potential upward pricing from any increased likelihood of coordination.

\section{F. Evasion of Regulation}

A vertical merger might be used to evade price regulation. But, in light of the Supreme Court's analysis in cases like Discon ${ }^{99}$ and Credit Suisse, ${ }^{100}$ the extent to which evasion of regulation remains a viable theory of harm (and, if so, what its limits are), arguably

98 Competitive Impact Statement, United States v. Premdor, Inc., No. 1:01-cv-01696 (D.D.C. Aug. 3, 2001), <www.justice.gov/atr/cases/f9000/9017.pdf>.

99 Nynex Corp. v. Discon, Inc., 525 U.S. 128 (1998).

100 Credit Suisse Securities (USA) LLC v. Billing, 551 U.S. 264 (2007). 
have become less clear. Revisions to the Vertical Merger Guidelines would need to resolve this issue. This resolution may depend on whether the merger leads to foreclosure or coordination in addition to pure evasion of the price ceilings intended by the regulations. It also might depend on whether the regulations preempt antitrust laws entirely. It also might depend on whether successful evasion could be rapidly detected and counteracted by the regulatory agency, whether the regulatory agency has the statutory and practical ability to punish evasion, and whether any regulatory impediments can be resolved by the regulator as part of its own merger approval process.

Example: The classic example is the pre-divestiture behavior of AT\&T, which allegedly used its purchases of equipment at inflated prices from its wholly-owned subsidiary, Western Electric, to artificially increase its costs and so justify higher regulated prices. ${ }^{101}$

Example: Potential evasion of regulation concerns were raised in the FTC's analysis in 2008 of the Fresenius/Daiichi Sankyo exclusive sublicense for a Daiichi Sankyo pharmaceutical used in Fresenius' dialysis clinics, which potentially could allow evasion of Medicare pricing regulations. ${ }^{102}$

The following information would be relevant to analysis of regulatory evasion concerns:

- Identification of any regulation of the prices or other competitive instruments of either of the merging firms.

- Determination of whether or not the merger could be used to evade that regulation, for example, whether cost-plus pricing regulation of the downstream firm could be evaded by raising the input price charged by the upstream division of the merged firm, or whether the regulations could be evaded by selling the products of the merging firms on a bundled basis.

- Evaluation of whether the evasion would be so costly to the merged firm that it would be unprofitable.

- Evaluation of whether the regulatory agency has the ability to review the merger and assess the merger's potential impact on regulatory evasion itself.

101 United States v. AT\&T, 524 F. Supp. 1336, 1370-75 (D.D.C. 1981)

102 In the Matter of Fresenius Medical Care AG \& Co. KGaA and Daiichi Sankyo Company, Ltd, No. 081-0146 (F.T.C. Sept. 15, 2008),

$<$ www.ftc.gov/sites/default/files/documents/cases/2008/09/080915freseniusanal.pdf>. 
- Evaluation of whether rapid detection and penalties levied by the regulatory agency would deter attempted regulatory evasion.

\section{G. Harmful Price Discrimination}

A vertical merger might permit a firm with pre-existing market power to price discriminate more effectively in the downstream market and harm one or more targeted groups of consumers. ${ }^{103}$ To price discriminate, a firm must be able to identify targeted customers and prevent arbitrage. As noted in the 2010 Horizontal Merger Guidelines, this sometimes can be done by creating product differences and pricing plans that lead consumers to self-sort while preventing effective arbitrage. ${ }^{104}$ By doing so, the merged firm in effect may gain additional market power over the targeted consumer group. ${ }^{105}$

This concern raises two potential legal and policy issues. First, if a vertical merger leads to lower prices for some consumers and higher prices for others, the consumers targeted for the price increase likely would comprise a separate market under the hypothetical monopolist test. ${ }^{106}$ Therefore, there is a legal issue of whether the benefits to the other consumers could be counted under Philadelphia National Bank. ${ }^{107}$ The policy issue is partially resolved in the 2010 Horizontal Merger Guidelines according to whether the benefits are inextricably linked and large, relative to the harms. However, this analysis may involve significant analytic and empirical difficulties in determining whether more effective price discrimination will be harmful or beneficial.

Second, this concern involves the merger leading to the increased exercise of preexisting market power, rather than achieving or maintaining market power. It sometimes has been argued that tying should be attacked only when it extends or

\footnotetext{
${ }^{103}$ More effective price discrimination does not always harm consumers. It is possible that it would permit a new product to be introduced. Sometimes it could lead to lower prices for some consumers without raising the prices to other consumers. These types of beneficial price discrimination would represent an efficiency benefit.

1042010 Horizontal Merger Guidelines §3.

105 The agencies would explain how competition for the targeted consumer group is lessened by eliminating their ability to benefit from the competition for the non-targeted consumers.

106 This article follows the 2010 Horizontal Merger Guidelines $\S 10$ in focusing on harm to consumers, rather than total welfare. As stated there, "the Agencies are mindful that the antitrust laws give competition, not internal operational efficiency, primacy in protecting customers."

107 United States v. Philadelphia Nat'l Bank, 374 U.S. 321, 370 (1963) ("If anticompetitive effects in one market could be justified by procompetitive consequences in another, the logical upshot would be that every firm in an industry could, without violating $\S 7$, embark on a series of mergers that would make it in the end as large as the industry leader.").
} 
maintains the market power of the tying product, for example, rather than when it simply permits the firm to exercise its market power more fully. ${ }^{108}$ However, in the case of a merger, the agencies would be challenging the merger that facilitates the exercise of market power through price discrimination, not the price discrimination itself. Therefore, there may fewer legal or policy hurdles.

Example: Price discrimination concerns were raised by the DOJ in 1995 in its review of the Sprint/Deutsche Telecom joint venture. ${ }^{109}$

The following information would be relevant to the evaluation of harmful price discrimination concerns:

- Evaluation of whether the merger would facilitate customer sorting or prevent arbitrage by increasing information or by bundling the sale of complementary products.

- Evaluation of whether the discrimination likely would lead to lower prices for some consumers, and if so, the relative impact on each group, or whether the discrimination likely would lead to lower (or higher) prices for all consumers.

- Evaluation of whether the discrimination likely would lead to higher or lower total output.

\section{H. Competitive Benefits}

A vertical merger may generate cognizable efficiency benefits that can lead to increased competition and, as a result, reverse potential anticompetitive impacts or deter the conduct that raises those concerns. In markets that are vulnerable to coordination, a vertical merger might reduce the likelihood of coordinated effects by the creation or enhancement of a maverick, or it might disrupt oligopoly coordination by decreasing the incentives to coordinate.

\section{Cognizable Efficiency Benefits}

A vertical merger potentially can generate a variety of efficiency benefits from vertical cooperation that improves communication flows and harmonizes the incentives of the merging firms. The benefits can include cost reductions and improved product design

108 See, e.g., Dennis W. Carlton \& Ken Heyer, Extraction v. Extension: The Basis for Formulating Antitrust Policy Towards Single-Firm Conduct, 4 COMPETITION POL'Y INT'L 285, 298 (2008)

109 Competitive Impact Statement, United States v. Sprint Corp., No. 95-cv-1304 (D.D.C. July 13,1995), <www.justice.gov/atr/cases/f0400/0452.pdf>. 
that can lead to lower prices, higher quality products, and increased investment. By reducing the cost of inputs used by the downstream division of the merged firm, a vertical merger also can create incentives for price reductions.

Vertical mergers sometimes are presumed to have greater efficiency benefits than horizontal mergers. However, there are many situations where vertical integration does not lead to efficiency benefits. Some types of efficiencies also may be more difficult to achieve than in a horizontal merger because the acquiring firm may lack expertise about the technology and business of the acquired firm. Thus, it cannot be assumed that significant cognizable efficiencies would occur in every vertical merger. Nor can it be assumed that efficiencies likely would be sufficient to reverse likely competitive harms.

In deciding whether efficiency benefits are cognizable, the analysis would follow the Horizontal Merger Guidelines in evaluating whether the claimed efficiencies are mergerspecific, verifiable, and involve procompetitive effects.

\section{a. Cost and Quality Efficiencies}

By reducing costs or increasing quality, the merged firm would obtain a unilateral incentive to reduce its quality-adjusted prices, all else held constant. This downward pricing pressure could offset or reverse the upward pricing pressure from the various sources discussed in this article. Evaluation of these efficiencies would largely be the same as in the context of horizontal mergers.

The following information would be relevant to evaluating this issue:

- If other firms in the market are integrated, evaluation of whether those integrated firms are generally more efficient and why.

- Identification of any expertise about the market by the downstream division of the merged firm that can be better shared with the upstream division of the merged firm if they are merged, or vice versa.

- Examination of whether and how information flows will improve if the firms are merged.

- Examination of any practical impediments to achieving these benefits absent the merger.

- Evaluation of whether any of these effects would lead to higher costs or reduced quality or services provided to other firms.

- Evaluation of any possible cost increases or other inefficiencies created by vertical integration, such as inefficient favoritism of inputs sold by the upstream division or greater complexity in dealing with firms that are now competitors. 
- Evaluation of whether these benefits would be sufficient to reverse the potential for competitive harms.

\section{b. Elimination of Double Marginalization}

Vertical mergers may lead to efficiency benefits when the upstream division of the merged firm charges a pre-merger price to the downstream division that exceeds its marginal costs. In this situation, the merger can lead the downstream division to treat the real resource cost of this input as equal to the marginal cost, regardless of the nominal input price charged by the upstream division. ${ }^{110}$ That reduction in the perceived real resource cost of the input can lead to the incentive to reduce its downstream prices. Economists refer to this mechanism by the term "elimination of double marginalization."

It might be argued that this prospect of this downward pricing pressure from elimination of double marginalization is a strong policy rationale to forgo all, or almost all, enforcement actions against vertical mergers. However, there are a number of strong economic reasons why elimination of double marginalization may be insufficient to trump the anticompetitive harms in many cases.

First, the downstream division's "opportunity cost" may not equal marginal cost. This reason relates to the unilateral incentives of the downstream division of the merged firm to raise price as a way to increase the profits of the upstream division. As discussed above, this incentive flows from the benefits to the upstream division of selling more inputs to rivals when the downstream division raises it price. ${ }^{111}$ This effect can reduce or reverse the effects of elimination of double marginalization.

Second, the upstream division of the merged firm and downstream division of the merged firm already may have a complex contract or relationship in the pre-merger world which reduces or eliminates double marginalization. This may involve a two-part tariff, complex pricing, or sufficient upstream competition such that the downstream firm already pays a price equal to or close to marginal cost on incremental units. Alternatively, it may involve quantity-forcing purchase requirements that lead to equivalent results.

Third, elimination of double marginalization benefits may not be merger-specific. It may be practical to arrange a contract as described above that achieves this benefit in the future without the merger.

110 Even if the transfer price is not set equal to marginal cost, an integrated firm could impose quantity-forcing contract on its downstream division in order to achieve the same benefit.

111 Section III.D . 
Fourth, it may not be economical for the downstream division of the merged to use the inputs of the upstream division of the merged firm because of product incompatibility or other reasons, in which case there is no double marginalization to be eliminated. ${ }^{112}$

Fifth, agency costs may lead some integrated companies to have their divisions treat one another at arm's length, in order to dampen competition between them or to compensate executives according to their performance and maintain the managerial efficiency of each division, which again would suggest that double marginalization would not be eliminated. ${ }^{113}$

All these reasons would suggest a policy by which this factor should be evaluated on a case-by-case basis along with other potential efficiency benefits and weighed against the prospect of competitive harms, just as is done for horizontal mergers. Elimination of double marginalization cannot simply be presumed.

Example: In Comcast/NBCU, both the FCC and the DOJ were skeptical of the claims that the merger would eliminate double marginalization because of premerger contractual terms and the opportunity cost (unilateral incentives) issue.

Example: In AT\&T/McCaw, McCaw's existing network infrastructure was incompatible with AT\&T's network equipment, so any elimination of double marginalization effect would be delayed. ${ }^{114}$

In some cases, these effects might be predicted from natural experiments arising from previous vertical mergers. When there is sufficient data available, elimination of double marginalization effects can be estimated and combined with the vGUPPId arising from the unilateral pricing incentives of the downstream division of the merged firm in order to evaluate the direction and magnitude of the net effect. ${ }^{115}$

The following information would be relevant to evaluating elimination of double marginalization benefits claims:

- Identification of whether the upstream division of the merged firm sells inputs to the downstream division of the merged firm.

112 For example, see Enghin Atalay, Ali Hortaçsu, Chad Syverson, Vertical Integration and Input Flows, 104 AM. ECON. REV. 1120 (April 2014).

${ }^{113}$ As discussed ( $n$ 110), this cannot simply be assumed from the fact that transfer pricing exceeds marginal cost.

114 Competitive Impact Statement, United States v. AT\&T Corp., No. 1:94-cv-01555 (D.D.C. July 15, 1994), <www.gpo.gov/fdsys/pkg/FR-1994-08-26/html/94-20948.htm>.

115 Section III.D . 
- Determination of whether the downstream merged firm would have the ability and incentive to substitute away from input purchases from non-merging firms to the inputs of the upstream division.

- Identification of the pre-merger incremental profit margin on input sales by the upstream division of the merged firm to the downstream division of the merged firm, in order to measure the potential magnitude of the beneficial effect.

- Identification of whether the firms currently have a complex contract (e.g., with a two-part tariff or quantity-forcing provisions) that reduces or eliminates double marginalization inefficiencies.

- If they do not currently have such a contract, examination of the reasons why the firms were unable to negotiate one and whether there are impediments other than the prospect of the merger to implementing such a complex contract in the future.

- If the upstream merging firm already is integrated in other ways, determination of the way in which inputs are priced to downstream divisions and how downstream divisions take those input costs into account in their decision-making.

- Evaluation of whether the merged firm's incentive to reduce the downstream price would be mitigated (or even reversed) by the fact that a reduction in the downstream price would reduce the profits earned by the upstream division of the merged firm on input sales to other downstream firms.

- Evaluation of the internal transfer prices and pricing practices of other integrated firms in the industry.

\section{c. Increased Investment Incentives}

Improved vertical cooperation from a vertical merger might lead to greater investment. A merger can improve communication and coordination between firms at different levels of production. A merger also can "internalize" the spillover benefits that investment by one of the firms has on the profitability of the other. ${ }^{116}$ The merger also can spur

\footnotetext{
116 For example, suppose that one of the firms has a potential investment that would cost $\$ 100$ and increase the NPV of its profits by $\$ 80$. Suppose it also would increase the NPV of the other firm's profits by $\$ 30$. The joint profits $(\$ 110)$ of this investment cover the investment costs $(\$ 100)$. However, the first firm would not be willing to undertake this investment unless the other firm shared the cost and such cost-sharing might face practical impediments. These
} 
investment by reducing the risk of hold-up. This risk can occur when one firm has to sink costs in anticipation of a long-term relationship with the other and there is fear of hold-up problems that cannot be resolved with a long-term contract. In such cases, common ownership through a vertical merger may be necessary for the investments to be profitable. In rare circumstances, an improvement in the ability to price discriminate might facilitate a rapid increase in investment, so that consumers would be benefited on balance.

The following information would be relevant to evaluating this potential benefit:

- Determining the magnitude of the spillover effects.

- Determining why the parties have been unable to or cannot internalize these spillover effects with cost sharing or a limited joint venture, and whether that type of cost sharing or limited joint venture might create anticompetitive effects of its own.

- Identification of long-term investments that are subject to hold-up by contracting partners.

- Evaluation of the impediments to eliminating this hold-up through contractual arrangements rather than a merger (e.g., transaction costs or inability to sufficiently specify contractual terms).

- Determination of the investment levels that would occur absent the merger.

- Evaluation of the harm to consumers and competition that would occur as a result of the reduced investment.

\section{Reduced Likelihood of Coordination}

While a vertical merger can increase the likelihood of coordination, ${ }^{117}$ it also may have the opposite effect in some circumstances and reduce the likelihood of coordination. The efficiency benefits of the merger or the structure of the merged firm may lead to the creation of a maverick firm. A vertical merger also may eliminate certain features of the pre-merger market that made successful coordinated behavior more likely.

The following information would be relevant to evaluating this potential procompetitive effect:

impediments could include bargaining behavior and limited information and control, which can lead to free rider issues.

117 See Section III.E. 
- Magnitude of merger-specific cost reductions or quality improvements, including elimination of double marginalization.

- Degree to which the pre-merger downstream market is vulnerable to or subject to coordination.

- Examination of whether the elimination of downstream coordination would benefit the merged firm on balance.

- Evaluation of whether cost reductions or other benefits would increase the incentives of the merged firm to become a maverick in the downstream market.

- Examination of whether the merged firm would have a greater ability to provide discounts without being detected, for example, by virtue of its participation in the downstream market as a vertically integrated firm.

- Examination of whether the change in market structure would make it more difficult for other upstream firms to observe the merged firm's level of upstream output or price.

- Examination of whether the merged firm would have a greater incentive to differentiate its product than before the merger.

- Evaluation of whether the merger would lead to greater cost asymmetry and thereby complicate reaching consensus on a coordinated price.

\section{Complementary Product Mergers}

The competitive effects analysis of complementary product mergers is very similar to the analysis of vertical mergers. As a matter of economics, the goods and services produced by firms at different levels of production (as in a vertical merger) are complements to one another. Complementary products sometimes are combined into packages and sold by one of firms, so they present as a vertical structure with the packaging firm treated as downstream. ${ }^{118}$ At other times, complementary products are sold separately and combined into packages by customers. In these cases, the identification of which product is upstream and which is downstream is a matter of convenience in explaining the theories of harms and benefits. ${ }^{119}$

\footnotetext{
118 For example, a customer planning a ski vacation can separately purchase the air travel, hotel, and lift ticket components separately or from a tour operator that does the packaging. Or, the customer might purchase the package from the airline, which separately purchases the hotel and lift ticket on a wholesale market.

119 One seeming difference between the analysis of vertical and complementary product mergers is that a final customer may want to purchase only one of the complementary components. For
} 
The competitive concerns and benefits from complementary product mergers generally have straightforward analogues in the vertical merger context. ${ }^{120}$ However, some issues may be described differently or may present themselves with different conduct than they would in the context of a vertical merger. These differences can lead to confusion by practitioners, if they are not understood.

Foreclosure concerns may involve conduct that appears different in form but is analytically similar. Like a vertical merger, a complementary product merger may involve a price increase for one of the components. However, the conduct might present itself differently as higher prices for purchasing the complementary products on an unbundled basis than for a bundle. Instead of an outright refusal to sell the upstream product, as may result from a vertical merger, a complementary products merger may involve a refusal to sell via post-merger product incompatibility. Or it may be implemented with physical or contractual tying, whereby the merged firm sells the one component to consumers only in a system or package with the other component produced by the merged firm.

Concerns about reduction in potential competition also can raise product incompatibility concerns in the complementary product merger context. To raise barriers to entry to firms that would produce only a single component, the merged firm might make its products incompatible with the likely designs of potential entrants or it might design proprietary interfaces.

In a complementary product merger where one of the firms assembles the products into a package to sell to consumers, elimination of double marginalization might be seen as identical as it would be in a vertical merger. In contrast, when complementary components are sold directly to consumers, the elimination of double marginalization may create an incentive for the merged firm to set lower prices only if the firms' complementary products are purchased as a bundle.

example, the customer planning a ski vacation may drive to the resort and so have no need for an airline ticket. However, this also can occur in the vertical merger context. A downstream firm similarly may engineer its product so that it does not use the input produced by the upstream division of the merging firms or its direct competitors. For example, electrically powered automobiles do not use fuel injectors or spark plugs.

120 The potential competitive harms discussed here should be distinguished from the so-called "entrenchment theory" in complementary product mergers. Under that theory, the efficiencies from the transaction might lead the merged firm to capture sales from its rivals sufficient to cause those rivals to exit. See, e.g., FTC v. Procter \& Gamble, 386 U.S. 568 (1967). This "efficiencies offense" is no longer treated as a cognizable theory of harm in the U.S. See, e.g., Speech, Deborah Platt Majoras, Deputy Assistant Attorney General, Antitrust Division, GEHoneywell: The U.S. Decision (Nov. 29, 2001), <www.justice.gov/atr/public/speeches/9893.htm>. 
Evaluation of complementary product mergers using the tools of vertical mergers has been the norm in the US. ${ }^{121}$ The proper characterization and treatment of complementary product mergers has raised some controversy in the past. In the GEHoneywell merger, the European Commission raised the issue that Honeywell's competitors might lose their "competitive strength" because they would be unable to match Honeywell's access to GE Capital's financial strength and the benefits of GE's vertical integration. ${ }^{122}$ These so-called "conglomerate effects" seemed to be attacking the merger because of its efficiency benefits, rather than its possible competitive harms to consumers from foreclosure. The European Commission's 2008 Non-Horizontal Guidelines clarified the focus on harm through input or customer foreclosure and coordinated effects. ${ }^{123}$

However, possibly as a result of continued concerns about the GE/Honeywell case, the 2012 ABA Taskforce was unable to reach consensus about whether to treat complementary product mergers in the same way as vertical mergers. ${ }^{124}$ In particular, Taskforce members held the view that complementary-product mergers raise fewer anticompetitive concerns, because they are more susceptible to post-merger challenge as tying or bundling than are comparable vertical effects. ${ }^{125}$ By contrast, others had the view that the effects in vertical and complementary-product mergers are economically identical, that post-merger enforcement risks irrevocable changes to the market structure, and that not all post-merger conduct (e.g., refusals to deal, unilateral price increases) would be so easily reachable under the antitrust laws. ${ }^{126}$ Thus, if the VMGs are revised, the treatment of complementary product mergers may require a policy decision by the drafters, if consensus cannot be achieved.

${ }^{121}$ For example, Northrop Grumman/TRW, GE/Avio and Live Nation/ TicketMaster each could be characterized as complementary product mergers. Many mergers could be characterized as either vertical or complementary. For example, NBCU was both an input and a complement for Comcast.

${ }^{122}$ See Commission Decision No. COMP/M.2220 (General Electric/Honeywell) (Mar. 7, 2001), ๆๆ 347-48.

${ }^{123}$ Commission Guidelines on the Assessment of Non-Horizontal Mergers under the Council Regulation on the Control of Concentrations Between Undertakings, 2008 O.J. C265/6 § V.

${ }^{124}$ ABA Report at 8-9. As noted, one of the authors was a member of that Taskforce.

${ }^{125}$ ABA Report at 8.

${ }^{126}$ ABA Report at 8-9. 


\section{J. Partial Ownership Acquisitions}

Partial acquisitions can raise competitive concerns when they involve vertical or complementary products. ${ }^{127}$ As with horizontal mergers, the analysis would examine the impact of the acquisition on the incentives of both firms and any exchanges of information entailed by the partial ownership interest. Even if the ownership interest is passive, competitive benefits and harms may still occur as a result of the acquiring firm sharing in the profits of the acquired firm. For example, the downstream division still may have a unilateral incentive (albeit at a reduced level) to both internalize the elimination of double marginalization and/or raise the downstream price. The upstream division still may have the unilateral incentive to raise price or restrict supply to the rivals of the downstream firm. A partial ownership interest also might reduce the ability and incentive of the parties to achieve other certain efficiency benefits.

Example: The FCC's analysis in News/Hughes in 2004 involved partial ownership issue. News Corporation was seeking approval to acquiring a $33-50 \%$ financial interest in DirecTV. ${ }^{128}$

Example: The FTC's analysis in the Time Warner/Turner transaction in 1997 involved partial ownership issues centering on the partial ownership by TCl. ${ }^{129}$

\section{Conclusions}

It seems clear that the 1984 Vertical Merger Guidelines are outdated and in need of revision. We hope that the analytics and suggested evidence set out here can facilitate that revision or serve as a good substitute until the revision actually occurs. However, this article cannot make the policy decisions that merging parties and courts also require. We therefore hope that this article hastens the revision of the Guidelines.

1272010 Horizontal Merger Guidelines § 13.

${ }^{128}$ Fed. Commc'ns Comm'n, Memorandum Opinion and Order, In re Applications of General Motors Corporation and Hughes Electronics Corporation, Transferors, and The News Corporation Ltd., Transferee, MB Dkt. No. 03-134, FCC Rcd. 03-330 (January 14, 2004), <https://apps.fcc.gov/edocs_public/attachmatch/FCC-03-330A1.pdf>

129 Time Warner Inc,123 F.T.C. 171 (1997), $<$ www.ftc.gov/system/files/documents/commission_decision_volumes/volume123/volume123a.pdf\#page=179>. 